Review

\title{
The Significance of NK1 Receptor Ligands and Their Application in Targeted Radionuclide Tumour Therapy
}

\author{
Agnieszka Majkowska-Pilip *(D), Paweł Krzysztof Halik ${ }^{(\mathbb{D}}$ and Ewa Gniazdowska ${ }^{(\mathbb{C}}$ \\ Centre of Radiochemistry and Nuclear Chemistry, Institute of Nuclear Chemistry and Technology, Dorodna 16, \\ 03-195 Warsaw, Poland \\ * Correspondence: a.majkowska@ichtj.waw.pl; Tel.: +48-22-504-10-11
}

Received: 7 June 2019; Accepted: 16 August 2019; Published: 1 September 2019

check for updates

\begin{abstract}
To date, our understanding of the Substance P (SP) and neurokinin 1 receptor (NK1R) system shows intricate relations between human physiology and disease occurrence or progression. Within the oncological field, overexpression of NK1R and this SP/NK1R system have been implicated in cancer cell progression and poor overall prognosis. This review focuses on providing an update on the current state of knowledge around the wide spectrum of NK1R ligands and applications of radioligands as radiopharmaceuticals. In this review, data concerning both the chemical and biological aspects of peptide and nonpeptide ligands as agonists or antagonists in classical and nuclear medicine, are presented and discussed. However, the research presented here is primarily focused on NK1R nonpeptide antagonistic ligands and the potential application of SP/NK1R system in targeted radionuclide tumour therapy.
\end{abstract}

Keywords: neurokinin 1 receptor; Substance P; SP analogues; NK1R antagonists; targeted therapy; radioligands; tumour therapy; PET imaging

\section{Introduction}

Neurokinin 1 receptor (NK1R), also known as tachykinin receptor 1 (TACR1), belongs to the tachykinin receptor subfamily of $G$ protein-coupled receptors (GPCRs), also called seven-transmembrane domain receptors (Figure 1) [1-3]. The human NK1 receptor structure [4] is available in Protein Data Bank (6E59). Tachykinins, widely distributed within the central (CNS) and peripheral (PNS) nervous system, are small bioactive neuropeptides which share a conserved C-terminal pentapeptide sequence, Phe-X-Gly-Leu-Met- $\mathrm{NH}_{2}$. Examples of these neurotransmitters belonging to the tachykinin group include Substance P (SP), the first neuropeptide discovered in mammals [5], neurokinin A (NKA) and neurokinin B (NKB). These compounds listed above are the preferential ligands for NK1, NK2 and NK3 receptors, respectively, although they can bind additional NK receptors with varying affinity [6]. 


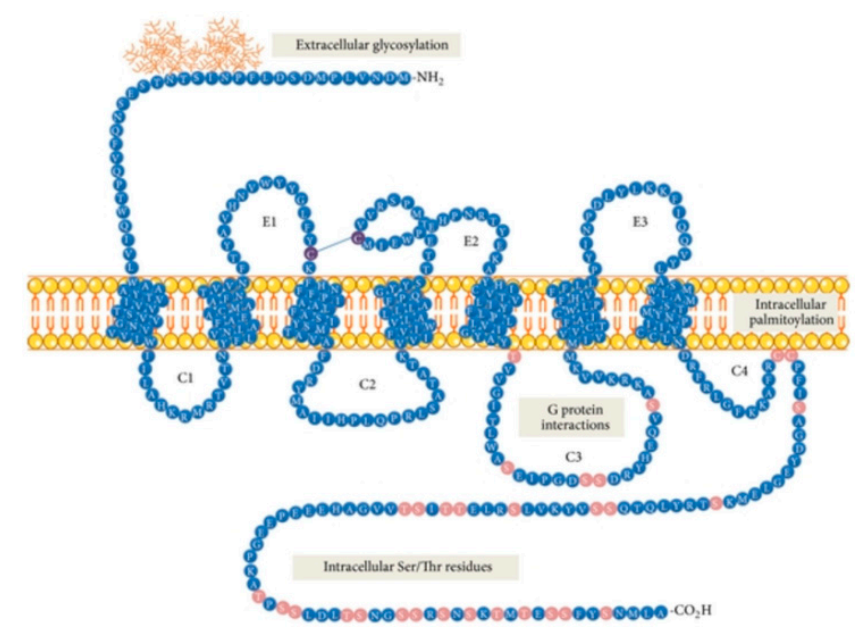

Figure 1. Schematic model of NK1 receptor of full length isoform (NK1R-Fl) [3].

Within the neurokinin receptor family, there are three pharmacologically distinct receptor subtypes: NK1R (TACR1, SPR), NK2R (TACR2) and NK3R (TACR3) [7-9]. NK1R is widely expressed in both the CNS and PNS, whereas NK2R is preferentially expressed in PNS [9]. NK1R contains 407 amino acids, and NK2R and NK3R (the longest one) consist of 398 and 465 amino acids, respectively [3]. NK1R exists in two isoforms, as a full-length peptide (NK1R-Fl, Figure 1) and in the truncated isoform (NK1R-Tr), containing 311 amino acids (96 amino acids less at the C-terminus) [3]. NK1R displays two nonstoichiometric binding sites, the more abundant NK-1M ("majority"-representing $80-85 \%$ of the total receptor population) and NK-1m ("minority"—so-called "septide sites" or "septide-sensitive") defined according to the different binding potencies of SP and its analogues [10-14]. NK1R contains an extracellular N-terminus, three extracellular loops (E1, E2 and E3), seven transmembrane domains, three intracellular loops (C1, C2 and C3, as well as a possible C4 loop) and an intracellular C-terminus.

The wide overexpression of NK1R in various human organs has led to successful development of highly selective agonists and antagonists of this receptor for the treatment of various diseases [8]. Some NK1R ligands, for example SP, its analogues and derivatives, have been investigated in preclinical and clinical studies. Moreover, based on high density of transmembrane NK1Rs on human cancer cells, new therapeutic approaches involve the use of radiolabelled NK1R ligands in targeted radionuclide tumour therapy [2,15-17].

The aim of this review is to discuss data from recent literature concerning the chemical and biological aspects of natural and synthetic NK1R ligands in classical and nuclear medicine, with a specific focus on targeted radionuclide therapy.

\section{NK1R Ligands in Classical Medicine}

\subsection{Significance of NK1R Agonists}

The endogenous peptide ligands of NK1R are tachykinins, a large family of neuropeptides produced by neuronal and glial cells $[5,18]$. These compounds play an important role in nociception, synaptic transmission (as excitatory neurotransmitters) and neuroimmunomodulation. They have a variety of effects on physiological and pathological conditions, as well as intrinsic neuroprotective and neurodegenerative properties [19]. The tachykinin family is characterized by a common C-terminal 5-amino-acid sequence Phe-X-Gly-Leu-Met- $\mathrm{NH}_{2}$, where $\mathrm{X}$ is either an aromatic (Phe or Tyr) or a branched chain aliphatic (Val or Ile) amino acid residue [19-21].

The most widespread and tested agonistic peptide ligand of NK1R is human endogenous undecaneuropeptide Substance P (Arg-Pro-Lys-Pro-Gln-Gln-Phe-Phe-Gly-Leu-Met-NH ${ }_{2}$, SP(1-11), SP, [Arg $\left.{ }^{1}\right] \mathrm{SP}$, Figure 2). At physiological $\mathrm{pH}$, SP characteristically holds a positive charge on $\mathrm{N}$-terminal amino acid residues. The C-terminus contains hydrophobic residues providing the SP peptide with 
an amphiphilic character [22]. The interaction between SP and NK1R results in internalisation of the membrane-bound complex, via a clathrin-dependent mechanism, to the acidified endosomes, where the complex disassociates [8,22-24].

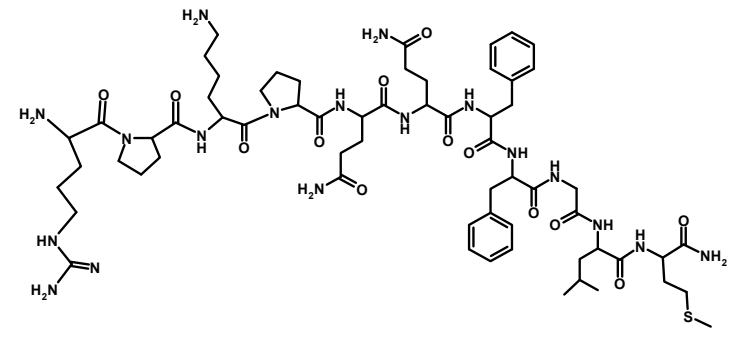

Figure 2. Structure of Substance $\mathrm{P}(1-11)$.

The SP fragment responsible for NK1R affinity is a five amino acid sequence, $\mathrm{Phe}^{7}-\mathrm{Phe}^{8}-\mathrm{Gly}^{9}-\mathrm{Leu}^{10}-\mathrm{Met}^{11}$, located at the C-terminus of the peptide $[21,25,26]$. Tachykinins are degraded by neutral endopeptidases (NEPs) and the angiotensin-converting enzyme (ACE) [27]. The half-life of SP ranges from seconds to $1.5 \mathrm{~h}$ in blood and tissues, while in extracted plasma SP is stable for hours [22]. In the biodegradation process the SP metabolites, SP(1-4), SP(1-5), SP(1-6), $\mathrm{SP}(1-7), \mathrm{SP}(8-9)$ and $\mathrm{SP}(10-11)$, can form as a results of enzymatic peptide cleavage at different sites [19,21,27-37]. Typical cleavage points are Lys-Arg, Arg-Arg and Arg-Lys doublets [19]. SP and NK1R are widely distributed in the CNS and PNS. SP mediates neural-immune/hematopoietic cross-talk [20] in the brain, and has specifically been isolated from the brain regions which regulate emotion (hypothalamus, amygdala and the periaqueductal gray) $[19,28]$. Additionally, SP plays an important role in the aetiology of many diseases [22]. It is thought that SP has a role in the regulation of depression and anxiety, emesis, pain, asthma, psoriasis, inflammatory bowel disease and in diseases of the CNS, including migraines and schizophrenia. The inhibition of NK1R stimulation via NK1R-specific secondary messenger pathways may be a useful in treatment in a variety of diseases. Concise information concerning the biological activity and the potential application of SP, its analogues and derivatives in medicine are presented in Table 1.

Multiple groups have recently published research concerning SP and its analogues or derivatives as agonistic or antagonistic peptide NK1R ligands [7,8,19,21,38-65]. New unnatural peptides are designed in order to improve their biological properties (e.g., half-life, receptor affinity and lipophilicity). Moreover, appropriate modifications can give peptides specific properties (e.g., photoactivation) or allow labelling with iodine radioisotopes or with other diagnostic/therapeutic radionuclides. NK1R has also been identified on various cancer cells, including astrocytoma, neuroblastoma, melanoma, and pancreatic cancer cells. NK1Rs have been implicated in tumour tissue growth and SP contributes to cancer volume increase, angiogenesis, proliferation and metastasis $[5,49,50]$. The authors of the patent "Radiolabeled conjugates based on substance P and the uses thereof" examined about ten different SP radiolabelled analogues (Table 2) in order to select optimal analogues in terms of stability and receptor affinity [53]. Endogenous SP is a potent vasodilator [54] and this action limits the application of SP-derived medical preparations. 
Table 1. Substance $P$, its analogues and derivatives: biological activity and potential application in classical medicine.

\begin{tabular}{|c|c|c|}
\hline NK1R ligands & Ligand Biological Properties and Applications & References \\
\hline \multicolumn{3}{|c|}{ Mammalian NK1R ligands } \\
\hline Substance P (SP, SP(1-11), [Arg $\left.\left.{ }^{1}\right] \mathrm{SP}\right)$ & $\begin{array}{l}\text { - Phosphatidylinositol signal pathway activation and } \\
\text { intracellular calcium concentration increase; } \\
\text { - Treatment of depression and associated anxiety; } \\
\text { - Prevention of vomiting after anaesthesia or chemotherapy; } \\
\text { - Increase of endothelial ion transport and permeability of } \\
\text { vessels in tissue inflammation states; } \\
\text { - Neuropathic pain modulation; } \\
\text { - Liver cirrhosis biomarker; } \\
\text { - Bone tissue metabolism modulator, especially of osteoblast } \\
\text { activity at a later stage of bone formation; }\end{array}$ & $\begin{array}{c}{[20]} \\
{[38]} \\
{[39,40]} \\
{[41-44]} \\
{[45]} \\
{[46-48]} \\
{[47,48]}\end{array}$ \\
\hline $\begin{array}{l}\mathrm{Arg}^{1}-\mathrm{Pro}^{2}-\mathrm{Lys}^{3}-\mathrm{Pro}^{4}-\mathrm{Gln}^{5}-\mathrm{Gln}^{6}- \\
\text { Phe }^{7}-\mathrm{Phe}^{8}-\mathrm{Gly}^{9}-\mathrm{Leu}^{10}-\mathrm{Met}^{11}-\mathrm{NH}_{2}\end{array}$ & $\begin{array}{l}\text { - Cancer growth promotor (astrocytoma, melanoma, } \\
\text { neuroblastoma, pancreatic cancer), angiogenesis, migration } \\
\text { and metastasis; }\end{array}$ & {$[5,49,50]$} \\
\hline (Figure 2) & $\begin{array}{l}\text { Study of the synergistic effect of SP and insulin-like growth } \\
\text { factor } 1 \text { (IGF-1) on corneal epithelial wound healing - } \\
\text { synergistic effect possible only in the presence of the SP } \\
\text { fragment containing minimum C-terminus } 4 \text { amino acids, } \\
\text { SP(8-11); }\end{array}$ & [51] \\
\hline $\begin{array}{c}{\left[\mathrm{Thi}^{8}{ }^{8} \mathbf{M e t}_{\left.\left(\mathbf{O}_{2}\right)^{\mathbf{1 1}}\right] \mathrm{SP}}\right.} \\
\text { Pro }^{4}-\mathrm{Gln}^{5}-\mathrm{Gln}^{6}-\mathrm{Phe}^{7}-\mathrm{Thi}^{8}-\mathrm{Gly}^{9}{ }^{-} \text {Leu }^{10}-\mathrm{Met}\left(\mathrm{O}_{2}\right)^{11}-\mathrm{NH}_{2}\end{array}$ & $\begin{array}{l}\text { Treatment of recurrent and critically located glioblastoma } \\
\text { multiforme; }\end{array}$ & [55] \\
\hline $\begin{array}{l}\text { [Sar }{ }^{9}, \text { Met }\left(\mathrm{O}_{2}\right)^{11}{ }^{11} \mathrm{SP}(1-11) \text { and }(\text { Sendide }) \\
{\left[\mathrm{Tyyr}^{6}, \mathrm{D}-\mathrm{Phe}^{7}, \mathrm{D}-\mathrm{His}^{9}{ }^{9} \mathrm{SP}(6-11)\right.}\end{array}$ & $\begin{array}{l}\text { Studies of the role of NK1R in regulation and release of } \\
\text { vasopressin peptide; }\end{array}$ & {$[56,57]$} \\
\hline 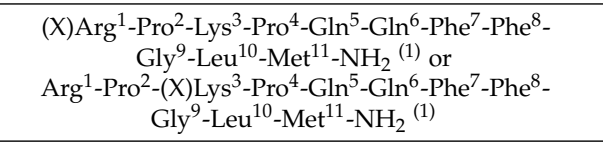 & Studies of photoactivatable SP derivatives; & [59] \\
\hline 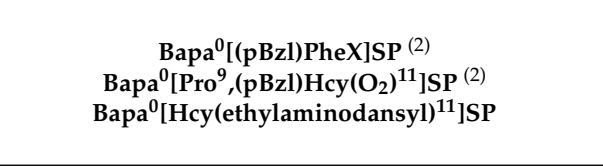 & $\begin{array}{l}\text { Studies of activation of different second messenger pathways } \\
\text { as a result of ligand binding to various NK1Rs sites; studies of } \\
\text { dual behaviour of the tested SP derivatives: as antagonists at } \\
\text { the NK-1M binding site activating AC pathway or agonists at } \\
\text { the NK-1m binding site activating PLC pathway; }\end{array}$ & [10] \\
\hline $\begin{array}{c}\text { Septide } \\
{\left[\text { [pGlu }^{6}, \text { Pro }^{9}\right] \mathrm{SP}(6-11)} \\
\text { pGlu }^{6}-\mathrm{Phe}^{7}-\mathrm{Phe}^{8}-\mathrm{Pro}^{9}-\mathrm{Leu}^{10}-\mathrm{Met}^{11}-\mathrm{NH}_{2}\end{array}$ & $\begin{array}{l}\text { Agonist as potent as SP in eliciting smooth muscle contraction, } \\
\text { however poor competitor of SP due to interaction with another } \\
\text { binding site of NK1R (NK-1m, so-called 'septide-sensitive'); }\end{array}$ & {$[7,60]$} \\
\hline $\begin{array}{c}\text { GR 73,632 } \\
\mathrm{NH}_{2}\left(\mathrm{CH}_{2}\right)_{4} \mathrm{C}(\mathrm{O})-\mathrm{Phe}^{7}-\mathrm{Phe}^{8}-\mathrm{Pro}^{9}-(\mathrm{Me}) \mathrm{Leu}^{10}{ }_{-} \\
\text {Met }^{11}-\mathrm{NH}_{2} \\
\end{array}$ & $\begin{array}{l}\text { Approximately 200-fold more potent than SP in inducing the } \\
\text { characteristic behavioural response in murine models. }\end{array}$ & [61] \\
\hline \multicolumn{3}{|c|}{ Non-mammalian NK1R ligands } \\
\hline $\begin{array}{c}\text { Physalaemin } \mathrm{Pyr}^{1}-\mathrm{Ala}^{2}-\mathrm{Asp}(\mathrm{OH})^{3}-\mathrm{Pro}^{4}- \\
\text { Asp }\left(\mathrm{NH}_{2}\right)^{5}-\mathrm{Lys}^{6}-\mathrm{Phe}^{7}-\mathrm{Tyr}^{8}-\mathrm{Gly}^{9}-\mathrm{Leu}^{10}-\mathrm{Met}^{11}-\mathrm{NH}_{2}\end{array}$ & $\begin{array}{l}\text { Stimulation of extravascular smooth muscles, component of } \\
\text { eye drops for Sjögren syndrome treatment and other forms of } \\
\text { keratoconjunctivitis sicca; }\end{array}$ & {$[3,19,62,63]$} \\
\hline $\begin{array}{l}\text { Eledoisin } \mathrm{pGlu}^{1}-\mathrm{Pro}^{2}-\mathrm{Ser}^{3}-\mathrm{Lys}^{4}-\mathrm{Asp}^{5}-\mathrm{Ala}^{6}-\mathrm{Phe}^{7}- \\
\mathrm{Ile}^{8}-\mathrm{Gly}^{9}-\mathrm{Leu}^{10}-\mathrm{Met}^{11}-\mathrm{NH}_{2}\end{array}$ & $\begin{array}{l}\text { Similar biological activities as Physalaemin but slightly less } \\
\text { active and more stable in vivo; clinical trials for limb } \\
\text { arteriosclerosis treatment; component of eye drops for Sjögren } \\
\text { syndrome; }\end{array}$ & {$[19,63]$} \\
\hline $\begin{array}{l}\text { Sialokinin I Asn }{ }^{2}-\mathrm{Thr}^{3}-\mathrm{Gly}^{4}-\mathrm{Asp}^{5}-\mathrm{Lys}^{6}-\mathrm{Phe}^{7}- \\
\text { Tyr }^{8}-\mathrm{Gly}^{9}-\mathrm{Leu}^{10}-\mathrm{Met}^{11}-\mathrm{NH}_{2} \\
\text { Sialokinin II, Asp }{ }^{2}-\mathrm{Thr}^{3}-\mathrm{Gly}^{4}-\mathrm{Asp}^{5}-\mathrm{Lys}^{6}-\mathrm{Phe}^{7}- \\
\text { Tyr }{ }^{8}-\mathrm{Gly}^{9}-\mathrm{Leu}^{10}{ }^{-\mathrm{Met}^{11}}-\mathrm{NH}_{2}\end{array}$ & $\begin{array}{l}\text { Vasodilation, effect on salivation, influence on the acinar cells } \\
\text { of the submandibular glands. }\end{array}$ & {$[3,64,65]$} \\
\hline
\end{tabular}


Table 2. The $\mathrm{IC}_{50}$ values determined for SP and various radiobioconjugates based on SP analogues [53].

\begin{tabular}{|c|c|}
\hline Substance & $\mathrm{IC}_{50} \pm \mathrm{SEM}[\mathrm{nM}]$ \\
\hline Substance P & $2.7 \pm 0.22$ \\
\hline${ }^{111}$ In-DOTAGA-Substance P & 1.1 \\
\hline${ }^{111}$ In-DOTAGA-[Met $\left.\left(\mathrm{O}_{2}\right)^{11}\right]$-Substance P & $9.8 \pm 1.00$ \\
\hline${ }^{111}$ In-DOTA-[Met $\left.\left(\mathrm{O}_{2}\right)^{11}\right]$-Substance P & $3.55 \pm 0.45$ \\
\hline${ }^{111}$ In-DOTA-[Sar $\left.{ }^{9}\right]$-Substance P & $3.20 \pm 0.30$ \\
\hline${ }^{111}$ In-DOTA-[Thi $\left.{ }^{8}\right]$-Substance P & $7.30 \pm 2.00$ \\
\hline${ }^{111}$ In-DOTA-[Thi $\left.{ }^{7}\right]$-Substance P & $9.40 \pm 1.60$ \\
\hline${ }^{111}$ In-DOTA-[Sar ${ }^{9}$,Met $\left.\left(\mathrm{O}_{2}\right)^{11}\right]$-Substance P & $2.00 \pm 0.00$ \\
\hline${ }^{111}$ In-DOTA-[Thi $\left.{ }^{8}, \operatorname{Met}\left(\mathrm{O}_{2}\right)^{11}\right]$-Substance P & $0.78 \pm 0.03$ \\
\hline${ }^{111}$ In-DOTA-[Thi ${ }^{8}$, Sar $\left.^{9}\right]-$ Substance P & $3.40 \pm 0.40$ \\
\hline${ }^{111}$ In-DOTA-[Thi ${ }^{7}$,Thi $\left.{ }^{8}\right]$-Substance P & $7.70 \pm 0.70$ \\
\hline
\end{tabular}

The autoradiography studies carried out on tumour tissues expressing NK1Rs revealed that ${ }^{111} \mathrm{In}$-DOTA- $\left[\mathrm{Thi}^{8}{ }^{8} \mathrm{Met}\left(\mathrm{O}_{2}\right)^{11}\right] \mathrm{SP}$ radiobioconjugate exhibited the highest affinity to examined receptors, therefore the SP analogue $\left[\mathrm{Thi}^{8}, \operatorname{Met}\left(\mathrm{O}_{2}\right)^{11}\right] \mathrm{SP}$ was used in further development for the synthesis of radiopharmaceuticals applied in medicinal experiments for recurrent, critically located glioblastoma multiforme (GBM) [55].

The SP derivatives agonistic ligand $\left[\mathrm{Sar}^{9}, \operatorname{Met}\left(\mathrm{O}_{2}\right)^{11}\right] \mathrm{SP}(1-11)$ and antagonistic ligand $\left[\mathrm{Tyr}^{6}{ }^{6}, \mathrm{D}-\mathrm{Phe}^{7}\right.$, ${ }^{D}-H_{i s}{ }^{9}$ SPP(6-11) (Sendide), along with others, were recently used to examine the role of NK1R in regulation and release of vasopressin peptide (AVP) from neurohypophysis [56,57]. Notably, it has been reported that replacement of L-amino acid by D-amino acid in the peptide results in antagonizing effects [21,58]. Numerous SP analogues (Table 1) with agonistic or antagonistic properties towards SP have been designed based on results of structure activity relationship (SAR) studies.

There are also non-mammalian NK1R ligands belonging to the tachykinin family. These compounds have distinctly different structure from SP, however in $\mathrm{COOH}$-terminal region they have similar pentapeptide sequence Phe-(Tyr/Ile)-Gly-Leu-Met- $\mathrm{NH}_{2}$ (often referred as the "message domain") [8,19,62-65] (Table 1). The non-mammalian tachykinins display the same spectrum of activity as the mammalian tachykinins and bind to the same receptors.

Taking into account the above information, it can be concluded that the measurement of the level of NK1Rs agonists (SP and its analogues), may be used as a diagnostic probe to inform about disease state. Nevertheless, literature shows the results of using NK1R agonists in application as drug active substances [19] (Table 1). Despite the existence of several examples of the use of NK1R agonists in therapy, it is anticipated that antagonists will be much more effective therapeutics.

\subsection{Application of NK1R Antagonists}

Despite the wide expression of the NK1R and the implication of SP in physiological regulation, NK1R antagonists remain infrequent in clinical use. Among NK1R antagonists aprepitant (MK-869, L-754,030) has been used to prevent of chemotherapy-induced nausea and vomiting (CINV) and obtained market registration (Emend ${ }^{\circledR}$, Merck) by United States Food and Drug Administration (US FDA) and European Medicines Agency (EMA) in 2003 [3,40,66]. Application in patients during moderate and acute emetogenic chemotherapy (e.g., cisplatin, doxorubicin or cyclophosphamide) was broadened by postoperative nausea and vomiting (PONV) indication two years after registration. In 2008, fosaprepitant (Ivemend ${ }^{\circledR}$, Merck), an intravenous prodrug of aprepitant, obtained FDA and EMA approvals. Aprepitant regimen [67-69] shows significantly higher response rates in CINV patients than the standard therapy $\left(5-\mathrm{HT}_{3} \mathrm{R}\right.$ antagonist ondansetron combined with corticosteroid dexamethasone). The antiemetic effect of aprepitant was reported to be due to the inhibition of high density NK1R brainstem regions (the area postrema and the nucleus solitarius) involved in the vomiting reflex [3]. Although aprepitant treatment is well tolerated, there may occur some gastrointestinal track and CNS mild adverse effects. This NK1R antagonist, importantly, is an inhibitor and inductor of xenobiotic metabolism fundamental cytochromes CYP3A4 and CYP2C9, respectively [67,70]. It is 
worth to keep in mind that aprepitant may affect the plasma concentration of many chemotherapeutics and dexamethasone (or other narrow therapeutic margin drugs like warfarin).

Additionally, in the CINV prevention, other NK1R antagonists have been evaluated, but only three obtained market authorization [71-75]. Rolapitant $\left(\right.$ Varubi $^{\circledR}$ or Varuby ${ }^{\circledR}$, Tesaro) received FDA and EMA approvals in human application, maropitant (Cerenia ${ }^{\circledR}$, Zoetis and Prevomax ${ }^{\circledR}$, Le Vet) received approval for the prevention of acute vomiting or vomiting due to motion sickness in veterinary clinics. Finally, netupitant, used in combination with the $5-\mathrm{HT}_{3} \mathrm{R}$ antagonist palonosetron, also received approval for human use (Akynzeo ${ }^{\circledR}$, Helsinn Birex). Casopitant (Rezonic ${ }^{\circledR}$ or Zunrisa ${ }^{\circledR}$, GlaxoSmithKline) nearly received approval, but GlaxoSmithKline withdrew its EMA authorization proposal following further safety assessments.

Many NK1R antagonists were explored as potentially therapeutic agents during early phase clinical trials [75-79]. A number of these were found ineffective or insignificantly useful in the treatment of major depressive disorder, depression, social anxiety, phobias, post-traumatic stress disorder, insomnia, schizophrenia, cannabis and opioid dependency, irritable bowel syndrome and overactive bladder, hot flashes, tinnitus and hearing loss, migraines, and painful diabetic polyneuropathy, and synergistically in antiviral HIV-1 therapy. Nevertheless, in a few studies of the NK1R antagonists, these compounds were revealed to be active in comparison to the placebo control. These successful reports refer to treatment of alcohol dependency (LY-686,017 case [80]) or chronic pruritus (aprepitant and serlopitant cases $[81,82])$.

On the other hand, great expectations are arising from the application of NK1R antagonists for the targeted treatment of malignant tumours. The antitumour action of NK1R antagonists (Table 3) was demonstrated in vitro on multiple human cell lines overexpressing NK1R as well as through in vivo research in xenograft murine models $[2,16,17,83-98]$.

Table 3. Anticancer effects of three most studied NK1R antagonists.

\begin{tabular}{|c|c|c|}
\hline NK1R Antagonists & Anticancer Effect & References \\
\hline \multirow{2}{*}{ Aprepitant } & Tumour cell growth inhibition & {$[2,16,17,83-98]$} \\
\hline & Tumour cell migration and proliferation inhibition & {$[2,16,17,83-98]$} \\
\hline \multirow{2}{*}{$\mathrm{L}-733,060$} & Apoptotic action on cells & {$[2,16,17,85-98]$} \\
\hline & Tumour size/volume decrease & {$[2,86,91,93-96]$} \\
\hline \multirow{2}{*}{ L-732,138 } & Inflammation state inhibition & {$[2,93,95,96]$} \\
\hline & Angiogenesis decrease & {$[2,16,86,91,93,95,96]$} \\
\hline \multirow{2}{*}{ (Figure 3) } & Antiproliferative effect & {$[2,16,86,91,93-96]$} \\
\hline & Metastases prevention & {$[2,86,91,93,95,96]$} \\
\hline
\end{tabular}

Recent studies refer to high specific antagonist nonpeptide agents, which efficiently compete with the SP/NK1R pathway. Despite structural differences of the presented antagonists (Figure 3), all cause direct receptor blockage correlated with a broad spectrum of anticancer effects. This pleiotropic activity may be highly valuable in terms of tumour treatment. Several NK1R ligands are also effective antiemetic agents. This is the case with aprepitant, the most studied NK1R antagonist with well-known pharmacokinetic and safety characteristics $[2,15,39,66-69,78,99]$. Alternatively, NK1R peptide ligand cyclosporine A, a commonly used immunosuppressive drug, also shows antitumour activity by binding to NK1R, as was demonstrated on various cancer cell lines [100,101].

Taken together, these reports suggest that NK1R antagonists may exert a wide range of potential therapeutic actions which may expand their clinical application. Despite the fact that there have been no oncological clinical trials executed to date to verify reported data, NK1R antagonists may prove to be a significant advance in the development of specific targeted antitumour therapy. 


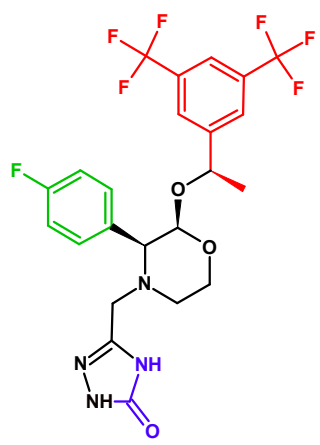

Aprepitant

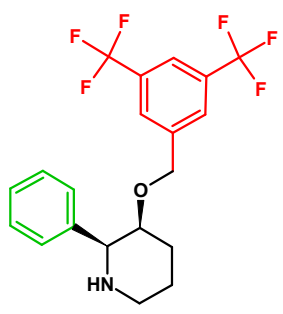

L-733,060

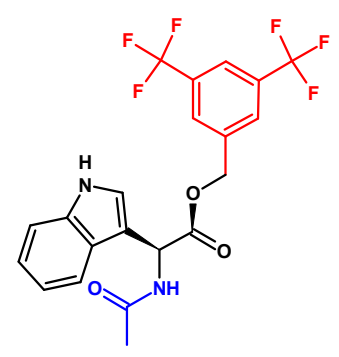

L-732,138

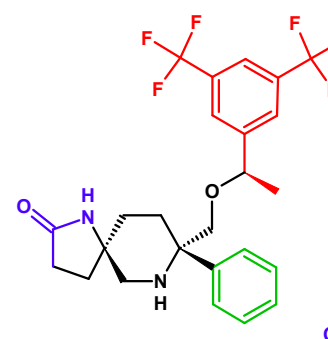

Rolapitant

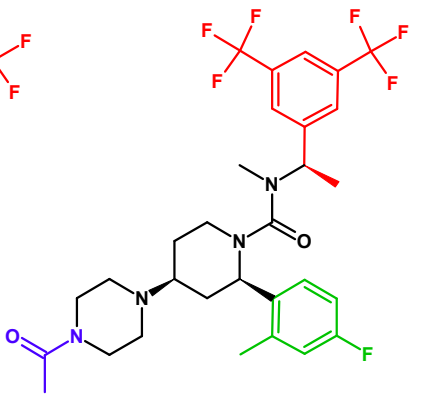

Casopitant

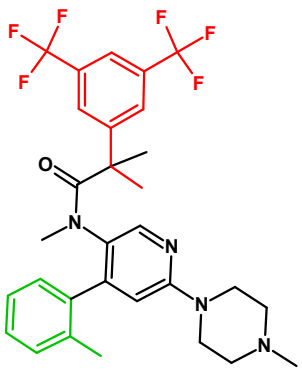

Netupitant<smiles>COc1ccc(C(C)(C)C)cc1CN[C@H]1C2CCC(CC2)C1C(c1ccccc1)c1ccccc1</smiles>

Maropitant

Figure 3. Colour visualisation of structure differences and similarities in the group of most antitumour evaluated NK1R antagonists (aprepitant, L-733,060 and L-732,138) and in group of CINV indicated NK1R antagonists (aprepitant, rolapinant, casopitant, netupitant and maropitant); the last presented, maropitant, despite the biggest structural distinction, showed high affinity to NK1R and sufficient clinical efficacy.

\section{NK1R Radioligands in Nuclear Medicine}

In nuclear medicine, ligands play the role of vectors leading medicine applied radionuclides to the target disease sites, which overexpress receptors for the implicated ligand. Radionuclide complexes are stable coordination compounds in which radionuclide cations are bonded by multidentate chelators (e.g., DOTA, NOTA, DOTAGA and DTPA). Syntheses of radioligands (radiopharmaceuticals) are performed according to the commonly known and described procedures, coupling reaction of ligand and bifunctional agent and labelling the obtained bioconjugate with the desired radionuclide.

\subsection{Radiolabelled NK1R Agonists for Targeted Radionuclide Tumour Diagnosis}

Diagnostic radiotracers (diagnostic radiopharmaceuticals) contain $\gamma$ or $\beta^{+}$-emitting radionuclides for SPECT and PET imaging, respectively. Radiopharmaceuticals are administered in such small amounts (at the nanomolar level) that they do not induce any pharmacological responses. After patient administration, the measurement of emitted gamma ray intensity allows for determination of the localization of the radiopharmaceutical and definition of tissue and organ abnormalities in the patient. These diagnostic methods enable detection of the biochemical and molecular pathologies at early disease stages, much earlier than the symptoms may be detected by the standard methods.

There are numerous studies describing the application of SP and its analogues or derivatives, labelled with diagnostic radionuclides (e.g., $\left.{ }^{68} \mathrm{Ga},{ }^{99 \mathrm{~m}} \mathrm{Tc},{ }^{111} \mathrm{In},{ }^{125} \mathrm{I}\right)$ designed for targeted radionuclide tumour diagnosis [102,103]. Table 4 presents concise information about published studies.

Nuclear characteristics of applied diagnostic radionuclides: ${ }^{3} \mathrm{H}$ : emitter $\beta^{-}, \mathrm{t}_{1 / 2}=12.32 \mathrm{y}$, $\mathrm{E}_{\max }=18.59 \mathrm{keV} ;{ }^{68} \mathrm{Ga}$ : emitter $\beta^{+}, \mathrm{t}_{1 / 2}=67.71 \mathrm{~min}, \mathrm{E}_{\text {mean }}=0.836 \mathrm{MeV} ;{ }^{99 \mathrm{~m}} \mathrm{Tc}$ : emitter $\gamma, \mathrm{t}_{1 / 2}=6.01 \mathrm{~h}$, 
$\mathrm{E}_{\max }=0.141 \mathrm{MeV} ;{ }^{111} \mathrm{In}$ : EC decay, emitter $\gamma, \mathrm{t}_{1 / 2}=2.80 \mathrm{~d}, \mathrm{E}_{\max }=0.245$ and $0.171 \mathrm{MeV} ;{ }^{125} \mathrm{I}$ : EC decay, emitter $\gamma, \mathrm{t}_{1 / 2}=59.41 \mathrm{~d}, \mathrm{E}_{\max }=27.47,27.20$ and $35.49 \mathrm{keV}$.

Table 4. Structure and potential application of NK1R diagnostic radioligands based on SP and its analogues or derivatives.

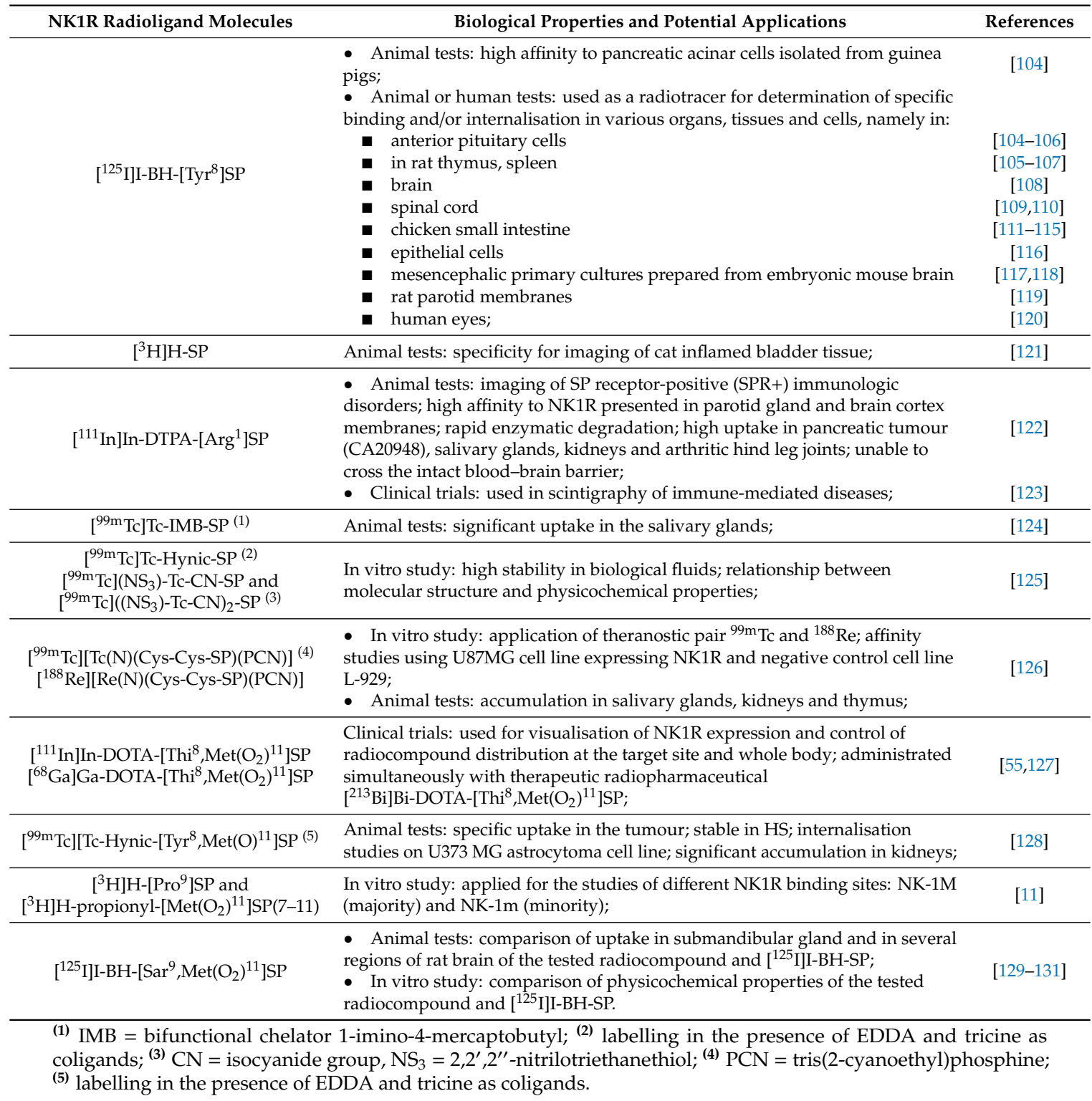

In order to label SP with the iodine-125 radionuclide, Phe in position 8 was replaced by Tyr. The $\left[\mathrm{Tyr}^{8}\right] \mathrm{SP}$ was radioiodinated with ${ }^{125} \mathrm{I}$ by the Bolton-Hunter agent (3-(3-iodo-4hydroxyphenyl)propionic acid $N$-hydroxysuccinimide ester, $\left.\left[{ }^{125} \mathrm{I}\right] \mathrm{I}-\mathrm{BH}\right)$. The experiments with radioligand $\left[{ }^{125} \mathrm{I}\right] \mathrm{I}-\mathrm{BH}-\left[\mathrm{Tyr}^{8}\right] \mathrm{SP}$ showed specific, rapid and temperature-dependent binding of radiobiomolecules, as well as internalisation into pancreatic acinar cells derived from guinea pigs [104]. The same Bolton-Hunter iodinated SP derivative was used as a radiotracer for characterization of its binding via autoradiography and/or internalisation into various organs, tissues and cells [104-120] (Table 4).

The radioligand $\left[{ }^{3} \mathrm{H}\right] \mathrm{H}-\mathrm{SP}$ was examined in order to determine accumulation in feline urinary bladder interstitial cystitis (IC) [121]. The results showed low uptake of $\left[{ }^{3} \mathrm{H}\right] \mathrm{H}-\mathrm{SP}$ in normal and inflamed tissues, while high accumulation was discovered in inflamed bladder tissue and small blood 
vessels. In this case $\left[{ }^{3} \mathrm{H}\right] \mathrm{H}-\mathrm{SP}$ appeared to be specific only for inflamed bladder of cats diagnosed with IC, possibly due to upregulation of NK1R as a part of the IC pathophysiology.

Further, the endogenous peptide SP has been used for syntheses of numerous radioligands. Radiobioconjugate [111 In]In-DTPA-[Arg ${ }^{1}$ ]SP was used for the in vivo detection of SP receptor-positive (SPR+) immunologic disorders and certain tumours [122]. The in vitro binding and autoradiographic experiments performed on parotid gland, brain cortex membranes and the submandibular gland of rat, demonstrated high affinity of [ $\left.{ }^{111} \mathrm{In}\right] \mathrm{In}$-DTPA-[Arg $\left.{ }^{1}\right]$ SP to NK1Rs. Tissue distribution of radioligand in male Wistar rats $24 \mathrm{~h}$ after treatment with $3 \mathrm{MBq}$ of $\left[{ }^{111} \mathrm{In}\right] \mathrm{In}$-DTPA-[Arg ${ }^{1}$ ]SP, revealed high concentration of radioactivity in the kidneys indicating renal excretion as the central route of radiobioconjugate elimination. The experimental results showed also rapid enzymatic degradation of the tested radiocompound resulting in an approximately $3 \mathrm{~min}$ half-life in blood. Interestingly, no significant uptake of [ $\left.{ }^{111} \mathrm{In}\right] \mathrm{In}$-DTPA-[Arg $\left.{ }^{1}\right]-\mathrm{SP}$ in the brain cortex and striatum was observed. These data suggested that the radiobioconjugate was unable to cross the intact blood-brain barrier (BBB) and further visualize SP receptors (SPRs) in the central nervous system. Additionally, $\left.{ }^{111} \mathrm{In}\right] \mathrm{In}-\mathrm{DTPA}-\left[\mathrm{Arg}^{1}\right]-\mathrm{SP}$ injected into rats bearing the autograft pancreatic tumour, CA20948, or rats with adjuvant mycobacteria tuberculosis-induced arthritic joints, exhibited significant uptake in the tumour, salivary glands, kidneys and arthritic hind leg joints. The authors further demonstrated the potential of this radiolabelled SP analogues for visualisation of pathological SPR+ processes in vivo by gamma camera scintigraphy.

The same $\left.{ }^{111} \mathrm{In}\right] \mathrm{In}-\mathrm{DTPA}-\left[\mathrm{Arg}^{1}\right] \mathrm{SP}$ radiobioconjugate was involved in the first clinical trials on twelve patients with immune-mediated diseases in 1996 [123]. After intravenous administration of 150-250 MBq of [111 In]In-DTPA-[Arg ${ }^{1}$ ]SP, rapid radiopharmaceutical degradation, within four minutes of treatment, was observed. Twenty-four hours postinjection, more than $95 \%$ of radioactivity was excreted in the urine. The uptake in areolae mammae (in women), liver, spleen, kidneys and urinary bladder was observed in all patients and in the thymus in eight patients. This radiobioconjugate can be used for scintigraphy of inflammatory sites in various diseases as well as for visualisation the thymus.

Studies of the diagnostic properties of ${ }^{99 \mathrm{~m}}$ Tc radiolabelled IMB-SP bioconjugate [124] have revealed uptake in the salivary glands, while the accumulation was decreased by factor of 2 in mice pretreated with excess of non-radiolabelled SP. The authors did not observe any cardiovascular side effects due to the slow rate of SP infusion.

SP ligand conjugated with Hynic chelator or monodentate bifunctional chelator isocyanobutyric succinimidyl ester and labelled with technetium-99m, [ $\left.{ }^{99 \mathrm{~m}} \mathrm{Tc}\right] \mathrm{Tc}-\mathrm{Hynic}-\mathrm{SP},\left[{ }^{99 \mathrm{~m}} \mathrm{Tc}\right]\left(\mathrm{NS}_{3}\right)-\mathrm{Tc}-\mathrm{CN}-\mathrm{SP}$ and [ $\left.{ }^{99 \mathrm{~m}} \mathrm{Tc}\right]\left(\left(\mathrm{NS}_{3}\right)-\mathrm{Tc}-\mathrm{CN}\right)_{2}$-SP have been synthesised and studied to determine potential application in targeted radionuclide tumour diagnosis [125]. The radiobioconjugates were characterized by high stability in the presence of competitive cysteine/histidine solutions and various lipophilicity $(\log \mathrm{P})$ values, of $-3.7,-0.24$ and -0.89 , respectively. SP ligands conjugated with two cysteine amino acids (Cys-Cys-SP) were used in the studies to apply ${ }^{99 \mathrm{~m}} \mathrm{Tc}$ and ${ }^{188} \mathrm{Re}$ as theragnostic matching pairs based on the combined reaction of tridentate $\pi$-donor and monodentate $\pi$-acceptor chelators with the $[\mathrm{Tc} / \mathrm{Re} \equiv \mathrm{N}]^{2+}$ metallic functional group [126]. [ $\left.{ }^{99 \mathrm{~m}} \mathrm{Tc}\right][\mathrm{Tc}(\mathrm{N})(\mathrm{Cys}-\mathrm{Cys}-\mathrm{SP})(\mathrm{PCN})]$ and $\left[{ }^{188} \operatorname{Re}\right][\operatorname{Re}(\mathrm{N})($ Cys-Cys-SP)(PCN)] radiobioconjugates incubated with U87MG cells expressing NK1R displayed predominant cell surface binding, whereas incubation with negative control cell line, L-929, resulted in no detectable interaction. Whole-body biodistribution studies using hybrid SPECT/CT YAP(S)PET small-animal tomography showed significant kidney and thymus uptake, in accordance with previous studies [123]. High radioactivity accumulation in salivary glands was also detected. The presented results ruled out myocardial uptake but did not confirm if the uptake of synthesised bioconjugates was specific.

The SP analogue $\left[\operatorname{Tyr}^{8}, \operatorname{Met}\left(\mathrm{O}_{2}\right)^{11}\right] \mathrm{SP}$ conjugated with DOTA chelator and labelled with diagnostic radionuclides ${ }^{111} \mathrm{In}$ or ${ }^{68} \mathrm{Ga}$ was used in glioma patient studies. The [111 $\left.\mathrm{In}\right] \mathrm{In}$-DOTA$\left[\mathrm{Thi}^{8}, \operatorname{Met}\left(\mathrm{O}_{2}\right)^{11}\right] \mathrm{SP}[55]$ and $\left[{ }^{68} \mathrm{Ga}\right] \mathrm{Ga}-\mathrm{DOTA}-\left[\mathrm{Thi}^{8}, \operatorname{Met}\left(\mathrm{O}_{2}\right)^{11}\right] \mathrm{SP}[127]$ receptor radiopharmaceuticals were injected simultaneously with therapeutic preparation $\left[{ }^{213} \mathrm{Bi}\right] \mathrm{Bi}-\mathrm{DOTA}-\left[\mathrm{Thi}{ }^{8}, \mathrm{Met}\left(\mathrm{O}_{2}\right)^{11}\right] \mathrm{SP}$ to visualise distribution of radiopharmaceuticals in the whole body. 
Similar to previous studies, SP analogue $\left[\operatorname{Tyr}^{8}, \operatorname{Met}(\mathrm{O})^{11}\right] \mathrm{SP}$ was applied for the synthesis of bioconjugate Hynic-[Tyr ${ }^{8}$,Met $\left.(\mathrm{O})^{11}\right]$ SP. The obtained bioconjugate, labelled with ${ }^{99 \mathrm{~m}} \mathrm{Tc}$, was used for detection of NK1R positive tumours [128]. The obtained radiobioconjugate was characterized with high specific activity (84-112 GBq/ $/ \mathrm{mol})$ and stability in human serum. Internalisation studies on U373 MG cells, an astrocytoma cell line, showed rapid (after $0.5 \mathrm{~h}$ ) binding of the tested compound to the cell membrane and specific internalisation. Saturation binding assays indicated a mean $K_{d}$ value in the nanomolar range, confirming the radioligand specificity to NK1R. Biodistribution studies in healthy mice and in tumour bearing nude mice demonstrated specific uptake in the tumour and the noticeable uptake in the stomachs, intestines and lungs, as well high accumulation in the kidneys, indicating excretion via the renal pathway. There was not significant accumulation in the salivary glands although this accumulation was moderately higher than in the other organs, including muscles and bones.

SP analogues $\left[\mathrm{Pro}^{9}\right] \mathrm{SP}$ and $\left[\operatorname{Met}\left(\mathrm{O}_{2}\right)^{11}\right] \mathrm{SP}(7-11)$ labelled with ${ }^{3} \mathrm{H}$ radionuclide were applied in studies of different NK1R binding sites [11]. The researchers examined internalisation of two radioligands, $\left[{ }^{3} \mathrm{H}\right] \mathrm{H}-\left[\mathrm{Pro}^{9}\right] \mathrm{SP}$ and $\left[{ }^{3} \mathrm{H}\right] \mathrm{H}$-propionyl $\left[\operatorname{Met}\left(\mathrm{O}_{2}\right)^{11}\right] \mathrm{SP}(7-11)$, using $\mathrm{CHO}$ cells transfected with human NK1Rs. The results showed existence of two nonstoichiometric binding sites NK-1M (majority) and NK-1m (minority). Both radiobioconjugates were internalized rapidly to achieve a maximum of $75 \%$ for specifically bound $\left[{ }^{3} \mathrm{H}\right] \mathrm{H}-\left[\mathrm{Pro}^{9}\right] \mathrm{SP}$ and of $35 \%$ for $\left[{ }^{3} \mathrm{H}\right] \mathrm{H}$-propionyl $\left.\left[\mathrm{Met}\left(\mathrm{O}_{2}\right)^{11}\right] \mathrm{SP}(7-11) .{ }^{3} \mathrm{H}\right] \mathrm{H}-\left[\mathrm{Pro}^{9}\right] \mathrm{SP}$ interacted with the most abundant NK-1M binding site inducing adenylyl cyclase activation (temperature dependent internalisation), whereas $\left[{ }^{3} \mathrm{H}\right] \mathrm{H}$-propionyl[Met $\left.\left(\mathrm{O}_{2}\right)^{11}\right] \mathrm{SP}(7-11)$ bound to the less abundant $\mathrm{NK}-1 \mathrm{~m}$ binding site connected with the phospholipase $\mathrm{C}$ (PLC) pathway (temperature independent internalisation).

The binding properties of the $\left[{ }^{125} \mathrm{I}\right] \mathrm{I}-\mathrm{BH}-\left[\mathrm{Sar}^{9}, \operatorname{Met}\left(\mathrm{O}_{2}\right)^{11}\right] \mathrm{SP}$ radiocompound based on the ligand $\left[\mathrm{Sar}^{9}, \operatorname{Met}\left(\mathrm{O}_{2}\right)^{11}\right] \mathrm{SP}$ were tested using autoradiography and compared with properties of [125I]I-BH-SP [129]. The results showed high uptake of both radiobiomolecules in the submandibular gland and in several regions of rat brain. Parallel in vitro binding experiments on rat brain membranes exhibited two to four fold higher affinity of $\left[{ }^{125} \mathrm{I}\right] \mathrm{I}-\mathrm{BH}-\left[\mathrm{Sar}^{9}, \mathrm{Met}\left(\mathrm{O}_{2}\right)^{11}\right] \mathrm{SP}$ than that of [ $\left.{ }^{125} \mathrm{I}\right] \mathrm{I}-\mathrm{BH}-\mathrm{SP}$. Despite higher affinity, $\left[{ }^{125} \mathrm{I}\right] \mathrm{I}-\mathrm{BH}-\left[\mathrm{Sar}^{9}, \mathrm{Met}\left(\mathrm{O}_{2}\right)^{11}\right] \mathrm{SP}$ did not demonstrate significantly higher specificity than [ $\left.{ }^{125} \mathrm{I}\right] \mathrm{I}-\mathrm{BH}-\mathrm{SP}$ in NK1R binding sites, in agreement with previous studies of these two radiobiomolecules [130]. However, autoradiographic data of $\left[{ }^{3} \mathrm{H}\right] \mathrm{H}-\left[\mathrm{Sar}^{9}, \mathrm{Met}\left(\mathrm{O}_{2}\right)^{11}\right] \mathrm{SP}$ reported in [131] showed slightly different localization of NK1Rs in the rat brain compared to previously presented data for $\left[{ }^{125}\right.$ I]I-BH-SP [130].

\subsection{Radiolabelled NK1R Agonists for Targeted Radionuclide Tumour Therapy}

Therapeutic radiopharmaceuticals used in cancer treatment or palliative therapy are often ligands labelled with radionuclides which emit corpuscular radiation of short range in the tissue (e.g., $\beta^{-}, \alpha$ or Auger electrons). Targeted radiopharmaceuticals characterized by high receptor affinity are selectively absorbed in the pathological tissues and their radiation energy is selectively and quantitatively deposited in the tumour mass. As a result, applications of these preparations are relatively safe for healthy tissues.

Nuclear characteristics of applied therapeutic radionuclides $[102,103]:{ }^{90} \mathrm{Y}$ : emitter $\beta^{-}, \mathrm{t}_{1 / 2}=64.00 \mathrm{~h}$, $\mathrm{E}_{\max }=2.28 \mathrm{MeV}$, mean tissue range: $2.76 \mathrm{~mm} ;{ }^{177} \mathrm{Lu}$ : emitter $\beta^{-}, \mathrm{t}_{1 / 2}=6.65$ days, $\mathrm{E}_{\max }=0.50 \mathrm{MeV}$, max. tissue range: $0.28 \mathrm{~mm} ;{ }^{213} \mathrm{Bi}$ : emitter $\alpha, \mathrm{t}_{1 / 2}=45.59 \mathrm{~min}, \mathrm{E}_{\max }=5.88$ and $5.56 \mathrm{MeV}$, tissue range: 40-100 $\mu \mathrm{m} ;{ }^{225}$ Ac: emitter $\alpha, \mathrm{t}_{1 / 2}=9.92 \mathrm{~d}, \mathrm{E}_{\max }=5.83$ and $5.80 \mathrm{MeV}$, tissue range: $40-100 \mu \mathrm{m}$.

In addition to the high incidence of NK1Rs in GBM, NK1Rs are overexpressed in approximately $27 \%$ of human pancreatic tumours [132]. Bortoleti de Araújo et al. applied endogenous SP for the synthesis of $\left[{ }^{177} \mathrm{Lu}\right] \mathrm{Lu}$-DOTA-SP radiobioconjugate (Table 5) and evaluated in vivo targeting of AR42J pancreatic tumour cells in Nude mice [133]. This study, along with others, reported that the radiobioconjugate was stable for more than $24 \mathrm{~h}$ at $37^{\circ} \mathrm{C}$ in human plasma. Biodistribution studies on AR42J pancreatic tumour bearing mice showed high uptake in kidneys, suggesting excretion mainly by 
renal pathway. Significant uptake of $\left[{ }^{177} \mathrm{Lu}\right] \mathrm{Lu}-\mathrm{DOTA}-\mathrm{SP}$ was also observed in intestine and stomach due to the presence of NK1Rs in the gastrointestinal tract. These results demonstrated the potential of $\left[{ }^{177} \mathrm{Lu}\right] \mathrm{Lu}-\mathrm{DOTA}-\mathrm{SP}$ as a treatment for pancreatic tumours.

Considering the high expression of NK1R on malignant glial brain tumours [132], studies of SP ligands have been initiated. The first in vivo studies concerned application of a SP with macrocyclic DOTAGA chelator, labelled with therapeutic radionuclides (mostly ${ }^{90} \mathrm{Y}$ and to reduce the "cross-fire effect", ${ }^{177} \mathrm{Lu}$ and ${ }^{213} \mathrm{Bi}$ ), were performed by Kneifel et al. [134]. In clinical experiments with twenty patients, the radiopharmaceutical was administered via an implanted catheter directly into the tumour mass or via intracavitary implant after surgical resection (the local injection minimizes side effects and reduces the tubular reabsorption of the radiopharmaceutical in the kidneys). Malignant glioma therapy of WHO grade 2 to 4 tumours, by applying $\beta^{-}$and $\alpha$ emitters, was well tolerated with low toxicity and resulted in the radiation induced necrosis of cancer cells. However, due to infiltrative characteristics of GBM, its complete surgical resection cannot be achieved. Therefore, the novel approach of neoadjuvant therapy, with the use of ${ }^{90} \mathrm{Y}$ radionuclide as the primary therapeutic modality, was proposed by Cordier et al. [135]. Seventeen patients with newly diagnosed and histopathologically confirmed GBM were treated with [ $\left.{ }^{90} \mathrm{Y}\right] \mathrm{Y}$-DOTAGA-SP before tumour surgical resection. The catheter systems were stereotactically implemented within the cancer margins and $\left[{ }^{90} \mathrm{Y}\right] \mathrm{Y}$-DOTAGA-SP radiopharmaceutical (radioactivity ranged from $120 \mathrm{mCi}$ to $345 \mathrm{mCi}$ ) was injected intratumorally. During the treatment, no increase or decompensation of intracranial pressure was observed. The pretreated tumours were demarcated by a capsule structure, leading to better separation from the cerebral tissue than in conventional glioma resection. Moreover, pseudo-encapsulation allowed for a marked reduction of intraoperative bleeding. The highest dose administered in ten patients caused the completed encapsulation of the tumour. This neoadjuvant local therapy was feasible without significant side effects, 15 of 16 patients treated so far exhibit stabilisation of neurological status. However, in critically located gliomas the use of ${ }^{90} \mathrm{Y}$ radionuclide with the resulting "cross-fire effect" may cause unacceptable damage of adjacent brain areas.

To minimize the neurological damage, the alpha radiation-emitting radionuclide ${ }^{213} \mathrm{Bi}$, which has a shorter range in tissue and higher radiation energy in comparison with ${ }^{90} \mathrm{Y}$ and ${ }^{177} \mathrm{Lu}$, was the first-line treatment [55]. Moreover, for the synthesis of novel radiopharmaceuticals, the $\left[\mathrm{Thi}^{8}, \mathrm{Met}\left(\mathrm{O}_{2}\right)^{11}\right.$ ]SP ligand, characterized by a longer half-life in vivo, was applied [53]. This SP analogue has been selected from various SP analogues tested (Table 2) in terms of the feasibility of vector application usage in targeted radionuclide tumour diagnosis or therapy. Pilot studies with $\left[{ }^{213} \mathrm{Bi}\right] \mathrm{Bi}-\mathrm{DOTA}-\left[\mathrm{Thi}^{8}{ }^{,} \mathrm{Met}\left(\mathrm{O}_{2}\right)^{11}\right] \mathrm{SP}$ and $\left[{ }^{111} \mathrm{In}\right] \mathrm{In}-\mathrm{DOTA}-\left[\mathrm{Thi}{ }^{8}, \operatorname{Met}\left(\mathrm{O}_{2}\right)^{11}\right] \mathrm{SP}$ were conducted in five patients diagnosed with critically located gliomas (WHO, grade 2-4) [55]. Similarly to previous clinical trials, the radioactive compound $\left.{ }^{213} \mathrm{Bi}\right] \mathrm{Bi}-\mathrm{DOTA}-\left[\mathrm{Thi}^{8}{ }^{8}, \mathrm{Met}\left(\mathrm{O}_{2}\right)^{11}\right] \mathrm{SP}$ was administered intratumorally via implanted catheters. Simultaneously, the $\left.{ }^{111} \mathrm{In}\right] \operatorname{In}-\mathrm{DOTA}-\left[\mathrm{Thi}^{8}{ }^{8}, \mathrm{Met}\left(\mathrm{O}_{2}\right)^{11}\right] \mathrm{SP}[55]$ or $\left[{ }^{68} \mathrm{Ga}\right] \mathrm{Ga}-D O T A-\left[\mathrm{Thi}^{8}{ }, \mathrm{Met}\left(\mathrm{O}_{2}\right)^{11}\right] \mathrm{SP}$ [127] radiocompounds were used for the visualisation of ${ }^{213} \mathrm{Bi}$-radiopharmaceutical distribution. Sixty to ninety minutes postinjection of $\left[{ }^{213} \mathrm{Bi}\right] \mathrm{Bi}-\mathrm{DOTA}-$ $\left[\mathrm{Thi}^{8}, \mathrm{Met}\left(\mathrm{O}_{2}\right)^{11}\right] \mathrm{SP}$, less than $4 \%$ of the activity was present in the blood, confirming high retention of this radiopharmaceutical in target site. The preliminary studies showed that this method is well tolerated and safe for patients; however, the short half-life of ${ }^{213} \mathrm{Bi}$ reduced the effectiveness of the treatment of larger tumours. Based on statistical data presented in the literature [127,136-138], the local treatment of brain tumours (intracavitary administration of radiopharmaceuticals) with the use of NK1R ligands in patients suffering from secondary GBM compares favourably with standard treatment options.

$\left[\mathrm{Thi}^{8}{ }^{2} \mathrm{Met}\left(\mathrm{O}_{2}\right)^{11}\right] \mathrm{SP}$ ligand was also used for in vitro studies of potential ${ }^{225} \mathrm{Ac}-$ radiopharmaceuticals for targeted therapy of NK1R expressing gliomas performed by Majkowska et al. [139]. The efficacy of $\left[{ }^{225} \mathrm{Ac}\right] \mathrm{Ac}-\mathrm{DOTA}-\left[\mathrm{Thi}^{8}, \mathrm{Met}\left(\mathrm{O}_{2}\right)^{11}\right] \mathrm{SP}$ was tested on three human glioblastoma cell lines (T98G, U87MG, U138MG), as well as GSCs. The binding experiments performed on T98G cells demonstrated high affinity $\left(\mathrm{K}_{\mathrm{d}}=19.2 \pm 1.9 \mathrm{nM}\right)$ of the radiobioconjugate 
for NK1R, which agrees with previous studies [140]. [ $\left.{ }^{225} \mathrm{Ac}\right] \mathrm{Ac}-\mathrm{DOTA}-\left[\mathrm{Thi}{ }^{8}, \mathrm{Met}\left(\mathrm{O}_{2}\right)^{11}\right] \mathrm{SP}$ caused significant reduction in glioblastoma cell viability compared to the conventional treatment with chemotherapeutic temozolomide. This radiobioconjugate has been shown to induce apoptosis and cell cycle arrest in G2/M phase. Importantly, $\left[{ }^{225} \mathrm{Ac}\right] \mathrm{Ac}-\mathrm{DOTA}-\left[\mathrm{Thi}{ }^{8}, \mathrm{Met}\left(\mathrm{O}_{2}\right)^{11}\right] \mathrm{SP}$ was found to be highly cytotoxic, not only towards established GBM cell lines, but also to GSCs cells which are particularly resistant to radio- and chemotherapy. According to the literature [141-143], these stem cells (variable from $1 \%$ or less in the case of low-grade tumours and to $30 \%$ in highly aggressive glioblastomas) are responsible for initiation of tumour formation in vivo, sustaining tumour growth, and contributing to the creation of metastatic lesions. Therefore, therapy which can target GSCs and GBM cells, such as $\left[{ }^{225} \mathrm{Ac}\right] \mathrm{Ac}-\mathrm{DOTA}-\left[\mathrm{Thi}^{8}, \operatorname{Met}\left(\mathrm{O}_{2}\right)^{11}\right] \mathrm{SP}$ therapy, may decrease the recurrence of gliomas and improve survival rate. Clinical trials using this radiobioconjugate have been initiated [144].

Table 5. Structure and potential application of NK1R therapeutic radioligands based on SP and its analogues or derivatives.

\begin{tabular}{|c|c|c|}
\hline NK1R Radioligand Molecules & Biological Properties and Potential Applications & Reference \\
\hline$\left[{ }^{177} \mathrm{Lu}\right] \mathrm{Lu}-\mathrm{DOTA}-\mathrm{SP}$ & $\begin{array}{l}\text { - Animal tests: biodistribution studies on mice bearing AR42J pancreatic } \\
\text { tumour, high uptake in kidneys, satisfactory uptake in tumour, significant } \\
\text { uptake in intestine and stomach; } \\
\text { - In vitro study: high specific uptake and internalisation using LN319 cells } \\
\text { isolated directly from the tumours; }\end{array}$ & [133] \\
\hline $\begin{array}{l}{\left[{ }^{177} \mathrm{Lu}\right] \text { Lu-DOTAGA-SP }} \\
{\left[{ }^{90} \mathrm{Y}\right] \mathrm{Y}-\mathrm{DOTAGA}-\mathrm{SP}} \\
{\left[{ }^{213} \mathrm{Bi}\right] \mathrm{Bi}-\mathrm{DOTAGA}-\mathrm{SP}}\end{array}$ & $\begin{array}{l}\text { Medical experiments: well tolerated therapy of critically located gliomas, } \\
\text { low toxicity; }\end{array}$ & [134] \\
\hline$\left[{ }^{90} \mathrm{Y}\right] \mathrm{Y}$-DOTAGA-SP & $\begin{array}{l}\text { Medical experiments: recorded completed encapsulation of the tumour in } \\
\text { patients administered with the highest dose; }\end{array}$ & [135] \\
\hline $\begin{array}{l}{\left[{ }^{213} \mathrm{Bi}\right] \mathrm{Bi}-\mathrm{DOTA}-\left[\mathrm{Thi}^{8}, \operatorname{Met}\left(\mathrm{O}_{2}\right)^{11}\right] \mathrm{SP}} \\
{\left[{ }^{111} \mathrm{In}\right] \mathrm{In}-\mathrm{DOTA}-\left[\mathrm{Thi}^{8}, \operatorname{Met}\left(\mathrm{O}_{2}\right)^{11}\right] \mathrm{SP}}\end{array}$ & $\begin{array}{l}\text { Medical experiments: treatment of critically located gliomas; well tolerated } \\
\text { and safe for patients; complete necrosis of small tumours and necrosis only in } \\
\text { the nearness of the implanted catheters in the case of large tumours; }\end{array}$ & [55] \\
\hline $\begin{array}{l}{\left[{ }^{213} \mathrm{Bi}\right] \mathrm{Bi}-\mathrm{DOTA}-\left[\mathrm{Thi}^{8}, \mathrm{Met}\left(\mathrm{O}_{2}\right)^{11}\right] \mathrm{SP}} \\
{\left[{ }^{68} \mathrm{Ga}\right] \mathrm{Ga}-\mathrm{DOTA}-\left[\mathrm{Thi}^{8}, \operatorname{Met}\left(\mathrm{O}_{2}\right)^{11}\right] \mathrm{SP}}\end{array}$ & $\begin{array}{l}\text { Medical experiments: treatment of patients with secondary GBM (after } \\
\text { surgery, chemo- and radiotherapy); very low accumulation in kidneys, urine, } \\
\text { bladder and blood; no side effects, necrosis and demarcation of the tumours; }\end{array}$ & [127] \\
\hline$\left[{ }^{213} \mathrm{Bi}\right] \mathrm{Bi}-\mathrm{DOTA}-\left[\mathrm{Thi}^{8}{ }^{8} \mathrm{Met}\left(\mathrm{O}_{2}\right)^{11}\right] \mathrm{SP}$ & $\begin{array}{l}\text { Medical experiments: higher efficiency of radiolabelled NK1R ligands } \\
\text { application and local brain tumours treatment in patients suffering from } \\
\text { secondary GBM compared to standard treatment options; }\end{array}$ & [136] \\
\hline$\left[{ }^{225}\right.$ Ac]Ac-DOTA- $\left[\mathrm{Thi}^{8}{ }^{8} \mathrm{Met}\left(\mathrm{O}_{2}\right)^{11}\right] \mathrm{SP}$ & $\begin{array}{l}\text { - In vitro study: high affinity to glioblastoma cancer cells: T98G, U87MG, } \\
\text { U138MG and glioblastoma stem cells (GSC); significant reduction in } \\
\text { glioblastoma cell viability in comparison to the conventional treatment with } \\
\text { temozolomide; high cytotoxicity towards GBM stem cells; } \\
\text { - Medical experiments: safe and well-tolerated therapy without side effects; }\end{array}$ & {$[139]$} \\
\hline $\begin{array}{l}{\left[{ }^{177} \mathrm{Lu}\right] \mathrm{Lu}-\mathrm{DOTA}-\mathrm{SP}(4-11)} \\
{\left[{ }^{177} \mathrm{Lu}\right] \mathrm{Lu}-\mathrm{DOTA}-\mathrm{SP}(5-11)} \\
{\left[{ }^{177} \mathrm{Lu}\right] \mathrm{Lu}-\mathrm{DOTA}-} \\
{\left[\mathrm{Thi}^{8}, \mathrm{Met}\left(\mathrm{O}_{2}\right)^{11}\right] \mathrm{SP}(5-11)}\end{array}$ & $\begin{array}{l}\text { In vitro study: radiobioconjugates characterized with higher lipophilicity } \\
\text { and lower molecular weight than those based on analogue } \\
{\left[\mathrm{Thi}^{8}, \mathrm{Met}\left(\mathrm{O}_{2}\right)^{11}\right] \mathrm{SP} \text { - changes in physicochemical properties of }} \\
\text { radiobioconjugates leading to their deeper diffusion into the cavity walls after } \\
\text { surgical resection of the tumour. }\end{array}$ & [145] \\
\hline
\end{tabular}

However, the main disadvantage of using $\left[\operatorname{Thi}^{8}, \operatorname{Met}\left(\mathrm{O}_{2}\right)^{11}\right] \mathrm{SP}$ ligand as a vector in ${ }^{213} \mathrm{Bi} /{ }^{225} \mathrm{Ac}$-radiopharmaceuticals is poor radiopharmaceutical diffusion into the walls of the postsurgical cavity. Following these results, fragments of SP ligand and its derivatives (SP(5-11), $\left.\mathrm{SP}(4-11),\left[\mathrm{Thi}^{8}, \mathrm{Met}\left(\mathrm{O}_{2}\right)^{11}\right] \mathrm{SP}(5-11)\right)$ were tested as potential vectors to guide the radiobioconjugate to the NK1Rs expressed on cancer cells [145]. These studies were focused on the synthesis of new radiobioconjugates with higher lipophilicity and lower molecular weight than those of $\left[\mathrm{Thi}^{8}{ }^{8}, \operatorname{Met}\left(\mathrm{O}_{2}\right)^{11}\right] \mathrm{SP}$. The new radiobioconjugates were projected to be more effective at diffusing into solid tumours or postsurgical cavity walls. The results of these studies showed that shorter fragments of SP were characterized by a lower molecular weight and higher lipophilicity, whereas the exchange of Phe for Thi in position 8 and Met for $\mathrm{MetO}_{2}$ in position 11 caused a decrease of lipophilicity. The newly prepared radiobioconjugates, such as $\left[{ }^{177} \mathrm{Lu}\right] \mathrm{Lu}-\mathrm{DOTA}-\mathrm{SP}(4-11)$ and $\left[{ }^{177} \mathrm{Lu}\right] \mathrm{Lu}-\mathrm{DOTA}-\left[\mathrm{Thi}^{8}{ }^{8}, \mathrm{Met}\left(\mathrm{O}_{2}\right)^{11}\right] \mathrm{SP}(5-11)$ exhibited satisfactory affinity to NK1Rs presented on U373 MG glioblastoma cells with $K_{d}$ values in the nanomolar range. Unfortunately, radiolabelled shorter 
fragments of SP in HS were less stable than in CSF due to fast enzymatic ligand biodegradation. Considering the lipophilicity, molecular weight, affinity and stability of SP, its fragments and analogues, a balance should be feasible. The relatively low ligand stability in HS does not completely disqualify the local treatment of radiolabelled short SP fragments, because the content of serum peptidases in the cavity after tumour resection is rather low. Nevertheless, the application of receptor radiopharmaceuticals requires individual consideration (personalised medicine) for each patient.

The above paragraphs of this review cover rich aspects of the biological properties and potential applications of NK1R agonist radioligands in targeted radionuclide diagnosis and therapy. The cited literature are quite consistent besides stability evidence of radiobioconjugates ${ }^{99 \mathrm{~m}} \mathrm{Tc}-\mathrm{Hynic}-\left[\mathrm{Tyr}^{8}-\mathrm{Met}(\mathrm{O})^{11}\right] \mathrm{SP}[128]$ and $\left[{ }^{177} \mathrm{Lu}\right] \mathrm{Lu}-\mathrm{DOTA}-\mathrm{SP}$ [133]. In contrast to plenteous literature, only these two papers provide data about radioligand stability in human serum. In our opinion this is questionable, due to endopeptidases present in HS leading to inevitable process of SP biodegradation.

Based on the data described in Sections 3.1 and 3.2, it is possible to conclude that NK1R ligands, labelled with diagnostic/therapeutic radionuclides, can be applied for imaging or therapy of cancers overexpressing the NK1Rs and for that these receptor radiopharmaceuticals are efficacious. This therapy seems to be prospective for the future in comparison to standard applied therapeutic options like temozolomide chemotherapy. Due to the relatively low stability of SP, its fragments and analogues, new NK1R ligands are constantly being investigated, starting innovative studies with the application of SP antagonists.

\subsection{Antagonist Radioligands of NK1R for Targeted Radionuclide Imaging}

A number of radiolabelled antagonists for NK1R are known to date. All radioligands exhibit high affinity to NK1R, but only some have potential future applications in targeted radionuclide tumour diagnosis or therapy. The features of those with potential are presented below (Table 6).

In contrast to SP and its peptide analogues, nonpeptide antagonists are stable and do not follow rapid enzymatic decomposition in vivo. First generation radiotracers were selected from many lead structures, based upon autoradiographic studies of NK1Rs. These compounds were initially investigated in vivo for their ability to be taken up by the brain and other organs in animal models [146-149] (Figure 4). Early evaluation of $\left[{ }^{11}\right.$ C]CP-96,345 [146] concluded that despite radioligand high lipophilicity, the cationic form excluded radiotracer passage through the blood-brain barrier and allowed for peripheral tissue imaging only. PET detection of central and peripheral NK1R occupancy was performed later on hamsters using $\left[{ }^{11} \mathrm{C}\right] \mathrm{CP}-99,994$ [147] and pigs using $\left[{ }^{11} \mathrm{C}\right] \mathrm{CP}-643,051$ [148]. Both studies confirmed the known autoradiographic mappings. The first primate PET imaging was reported in 2000 at the Uppsala University PET Centre [149], and revealed the uptake kinetics of $\left[{ }^{11} \mathrm{C}\right]$ GR205171 ([11 C]vofopitant) (Figure 5). Research includes regular imaging (baseline study) and imaging with receptor blocked active sites (using unlabelled compound) to demonstrate high specific binding in the striatum, thalamus and neocortex. Tracer analysis showed rapid uptake during $50 \mathrm{~min}$ of examination and fast cerebellar nonspecific washout, which introduced the possibility of in vivo assessment of receptor distribution. At the same time, the slow dissociation rate of this tracer from NK1Rs excludes dynamic PET imaging using $\left[{ }^{11} \mathrm{C}\right]$ GR205171 for physiological receptor regulations. Thereby, the tracer evaluations in human were focused on brain NK1R mapping for further potential clinical application. 
<smiles>[124CH3]Oc1ccccc1CN[C@H]1C2CCN(C2)[C@H]1C(c1ccccc1)c1ccccc1</smiles>

$\left[{ }^{11} \mathrm{C}\right] \mathrm{CP}-96,345$<smiles>COc1ccccc1CN[C@@H]1CCCN[C@H]1c1ccccc1</smiles>

$\left[{ }^{11} \mathrm{C} \mid \mathrm{CP}-99,994\right.$<smiles>COc1ccc(OC(F)(F)F)cc1CN[C@@H]1CCCN([14CH3])[C@H]1c1ccccc1</smiles>

$\left[{ }^{11} \mathrm{C}\right] \mathrm{CP}-643,051$

Figure 4. Structures of the first radioligands of neurokinin 1 receptor.

Alternative research were performed using similar highly specific radiotracer $\left[{ }^{18} \mathrm{~F}\right] \mathrm{SPA}-\mathrm{RQ}$, a ${ }^{18}$ F-labelled derivative of vofopitant (Figure 5), US patented by Merck \& Co. in 2001 and investigated mainly in Merck Research Laboratories (West Point, Pennsylvania) and Turku Positron Emission Tomography Centre. The influence of gender and age on NK1R availability was investigated using $\left[{ }^{18}\right.$ F]SPA-RQ 3D PET imaging [150], including 35 male and 10 female volunteers, aged 19 to 55 years. Results revealed a significant relationship of general $7 \%$ decrease rate of cerebral NK1Rs per decade of life, caused by physiological aging. This phenomenon was observed in frontal, temporal, parietal cortex and hippocampus structures. Moreover, NK1R availability, especially in the striatum, was found to be relatively lower in women than in men, what was later confirmed using $\left[{ }^{11} \mathrm{C}\right] \mathrm{GR} 205171$. Indeed, further investigations [151] provided data of similar interaction effects of age and sex on cerebral receptor availability using this radiotracer. These results indicated similar declines in the rate of NK1 receptor density in the frontal, temporal, and occipital cortices, but also in the brainstem, thalamus and caudate nucleus per each decade of life. Surprisingly, receptor availability loss in the amygdala and temporal cortex with an age increase was noted only in men. Additionally, in this study women showed lower general NK1R density in the thalamus compared to male volunteers.

$\left[{ }^{18} \mathrm{~F}\right] \mathrm{SPA}-\mathrm{RQ}$ and $\left[{ }^{11} \mathrm{C}\right] \mathrm{GR} 205171$ are based on the same pharmacophore. Both demonstrate fast brain uptake and very high affinity for NK1R with low nonspecific binding. Both radioligands enable efficient parametric PET imaging via a simple method based on reference ratio of region of interest (ROI) signal to cerebellar signal. This is a capability of the radioligands referenced due to fast washout of nonspecific bond tracer in the cerebellum bereft of NK1Rs. All of these features favour application of both radiotracers in localization and quantification of receptor studies in course of targeted radionuclide therapy.<smiles>COc1ccc(-n2nnnc2C(F)(F)F)cc1CNC1CCCNC1c1ccccc1</smiles>

$\left[{ }^{11} \mathrm{C}\right] \mathrm{GR205171}$

$\left[{ }^{11} \mathrm{C}\right]$ vofopitant<smiles>FCOc1ccc(-n2nnnc2C(F)(F)F)cc1CNC1CCCNC1c1ccccc1</smiles>

$\left[{ }^{18} \mathrm{~F}\right] \mathrm{SPA}-\mathrm{RQ}$

$\left[{ }^{18} \mathrm{~F}\right] \mathrm{L}-829,165$

Figure 5. Twin structures of radiotracers $\left[{ }^{11} \mathrm{C}\right] \mathrm{GR} 205171$ and $\left[{ }^{18} \mathrm{~F}\right] \mathrm{SPA}-\mathrm{RQ}$. 
Preclinical evaluation of PET NK1R imaging in human brains, using $\left[{ }^{18} \mathrm{~F}\right] \mathrm{SPA}-\mathrm{RQ}$, was performed in terms of further investigations of NK1R antagonists, accurate receptor neurodistribution and influence of receptor regulation on CNS pathologies. PET 3D studies [152] detailed multiple observations including the highest uptake of the radiotracer at the putamen and caudate, followed by uptake rates in adjacent substantia nigra and globus pallidus structures. Uniform and moderate uptake of radiotracer was widespread in limbic cortex and neocortex regions, while inconsiderable specific uptake was observed in the cerebellum. Autoradiographic post-mortem studies on the human brain confirmed similar affinity. However, examination via kinetic modelling revealed a few drawbacks among visualisation procedure. First, the low rate of radiotracer kinetics required a six hour time period for the binding equilibrium to occur (Figure 6). This time impacted imaging quality and reliability, but also favoured the radioactive agent metabolic decomposition; 90 min after injection, only $40 \%$ of the radioactivity in plasma still represented the initial $\left[{ }^{18} \mathrm{~F}\right] \mathrm{SPA}-\mathrm{RQ}$ concentration. Moreover, free fluoride was observed, likely resulting in the skull bone radioactivity that was observed during late scans In the end, a simplified reference tissue kinetic model of the radiotracer uptake was optimized. After $240 \mathrm{~min}$, data acquisition was optimal, corresponding to set binding potential (BP, a combined measure of the density of "available" neuroreceptors and the affinity of a drug to this neuroreceptor). BP values were assigned from 4 to 5 in the basal ganglia structures and between 1.5 and 2.5 in the cortical regions, in reference to the cerebellum. Researchers also suggested that for clinical imaging utility, a commonly applied ratio method considering cerebellar reference is reliable and preferable, as it does not require arterial blood sampling and long acquisition time.
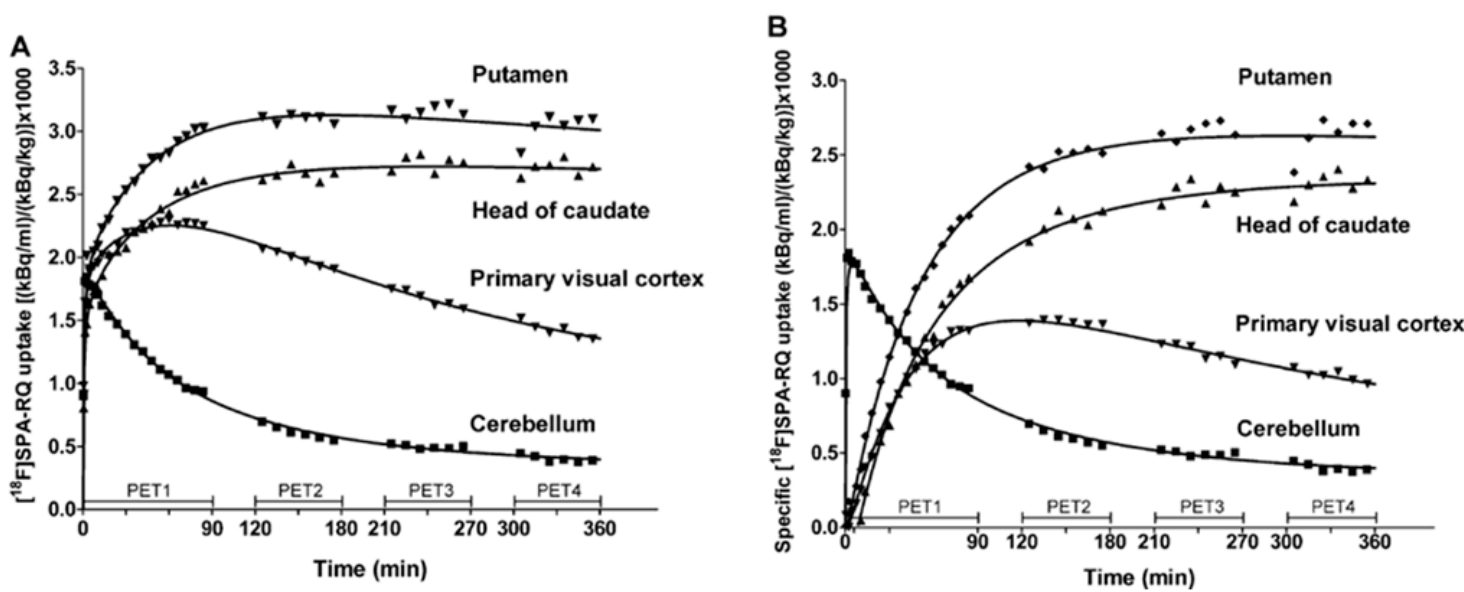

Figure 6. $\left[{ }^{18} \mathrm{~F}\right] \mathrm{SPA}-\mathrm{RQ}$ radiotracer total $(\mathrm{A})$ and specific $(\mathbf{B})$ uptake values in function of time in striatal structures and occipital cortex. As reference, both charts present cerebellar total binding curves [152].

In support of these measurements, a similar radioligand $\left[{ }^{18} \mathrm{~F}\right]$ fluoroethyl-SPA-RQ ( $\left.\left[{ }^{18} \mathrm{~F}\right] \mathrm{FE}-\mathrm{SPA}-\mathrm{RQ}\right)$, with high affinity and selectivity to NK1R was developed and examined $[153,154]$. $\left[{ }^{18} \mathrm{~F}\right] \mathrm{FE}-\mathrm{SPA}-\mathrm{RQ}$ featured lower in vivo defluorination relative to the previous analogue, $\left[{ }^{18} \mathrm{~F}\right] \mathrm{SPA}-\mathrm{RQ}$, seen via reduced radioactivity in bone accumulation. A group from the Japanese Molecular Imaging Centre (National Institute of Radiological Sciences, Chiba, Japan) examined [ $\left.{ }^{18} \mathrm{~F}\right] \mathrm{FE}-\mathrm{SPA}-\mathrm{RQ}$ characteristics on primates and rodents. These studies were followed by PET imaging with kinetic modelling to validate visualisation and quantification of NK1R distribution in healthy men. Although similar $\left[{ }^{18} \mathrm{~F}\right] \mathrm{SPA}-\mathrm{RQ}$ and $\left[{ }^{18} \mathrm{~F}\right] \mathrm{FE}-\mathrm{SPA}-\mathrm{RQ}$ imaging of distribution on human brain receptors was observed; BP values obtained for $\left[{ }^{18} \mathrm{~F}\right] \mathrm{FE}-\mathrm{SPA}-\mathrm{RQ}$ were lower, in fact, $\left[{ }^{18} \mathrm{~F}\right] \mathrm{FE}-\mathrm{SPA}-\mathrm{RQ}$ showed little higher affinity for NK1R than $\left[{ }^{18} \mathrm{~F}\right] \mathrm{SPA}-\mathrm{RQ}$.

All of these explorations enable further investigations of NK1R system contribution in targeted radionuclide therapy of CNS pathologies. So far, several early phase clinical trials using the discussed radiotracers have been conducted. Temporal lobe epilepsy [155] and social anxiety disorder [156] PET studies using [ $\left.{ }^{11} \mathrm{C}\right]$ GR205171 were performed in small studies comparing NK1R availability in specific 
cerebral structures of patients and healthy control subjects. In both studies, applied radiotracer imaging provided positive correlations between increased receptor availability and patient neuropathology. More precisely, significant enhanced in NK1R availability was determined in the ipsilateral and contralateral hemispheres of the temporal lobe in epileptic patients and in the right amygdala in patients with social anxiety disorder (Figure 7). Moreover, increased receptor availability correlated with epileptic seizure frequency in ipsilateral medial temporal structures. Another $\left[{ }^{11} \mathrm{C}\right]$ GR205171 imaging study was performed on healthy volunteers with snake or spider phobias to investigate the effect of fear stimuli on NK1R availability [157]. During PET acquisitions, subjects were provoked by normal and fear stimulating animal pictures to distinguish baseline and fear stimulated scans of NK1R occupancy imaging. As a result, provocation of specific phobia had influence on signals in the right amygdala, which suggested that fear stimulated the release of endogenous SP in that region of the brain. Taken together, these findings demonstrate that $\left[{ }^{11} \mathrm{C}\right] \mathrm{GR} 205171$ voxel-based statistical analysis can substantially support NK1R mapping in specific anxiety, stress and epileptic disorders.

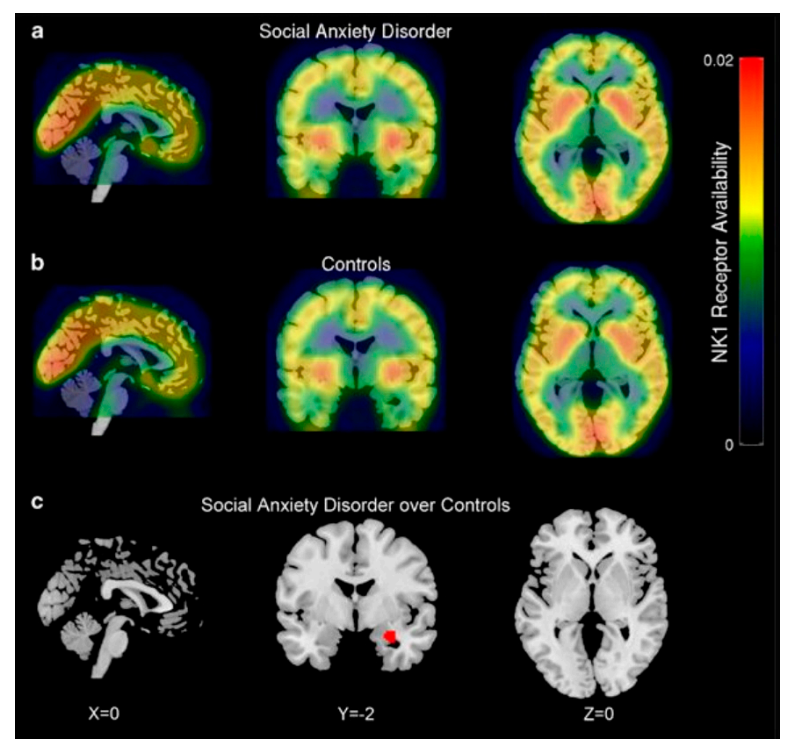

Figure 7. $\left[{ }^{11} \mathrm{C}\right] \mathrm{GR} 205171 \mathrm{PET} / \mathrm{MRI}$ imaging of NK1R occupancy in social anxiety disorder patients (a) and healthy controls (b). Mean PET parametric scans (in colour) of radiotracer were overlaid on MRI images and compared between both groups. Patients with social anxiety disorder showed increased NK1 receptor availability in the right amygdala (c) [156].

$\left[{ }^{18} \mathrm{~F}\right] \mathrm{SPA}-\mathrm{RQ}$ was also employed in the quantification of NK1Rs in the brains of patients with panic disorder $[158,159]$. Baseline PET imaging and imaging after pharmacological induction of panic attacks were performed in patients and healthy volunteer cohorts. The result revealed a significant reduction of NK1Rs at baseline in patients compared with healthy subjects in all brain ROIs (12\% to $21 \%$ reduction). Although this is in contrast to the above study focused on patient with social anxiety disorder, a similar outcome was demonstrated when two groups of female subjects were compared, with and without Irritable Bowel Syndrome [160]. Based on PET imaging supported with MRI scans, comparison of cerebral NK1R density revealed lower $\left[{ }^{18} \mathrm{~F}\right] \mathrm{SPA}-\mathrm{RQ}$ binding levels in patients in the globus pallidus. This radiotracer was also used in trials focused on post-traumatic stress disorder [161] and effective PET quantification of pancreatic cancer lesions for targeted radionuclide tumour therapy [162].

Meanwhile, it should also be noted that radiotracer molecular imaging is increasingly being used to determine receptor pharmacodynamics and optimize applicable effective doses of novel NK1R antagonists. One of the first clinical trials focused on this inspected a highly selective antagonist, aprepitant, while it was undergoing market authorisation. Determination of relationship between brain NK1R occupancy levels and aprepitant oral dose or plasma concentration was explored using $\left[{ }^{18} \mathrm{~F}\right] \mathrm{SPA}-\mathrm{RQ}$ in single-blind, randomised, placebo-controlled studies in healthy participants [163]. 
Indeed, reliable cerebral NK1R occupancy prediction, according to aprepitant plasma concentration was determined. More than $90 \%$ of striatal receptor occupancy was reached in subjects with aprepitant plasma concentration around $100 \mathrm{ng} / \mathrm{mL}$, after $>100 \mathrm{mg} /$ day of aprepitant for 2 weeks. Even though the study was conducted with a limited number of subjects and small variety of doses, it provided valuable indications for dosage regimens by which to achieve effective receptor blockage in the CNS (Figure 8).

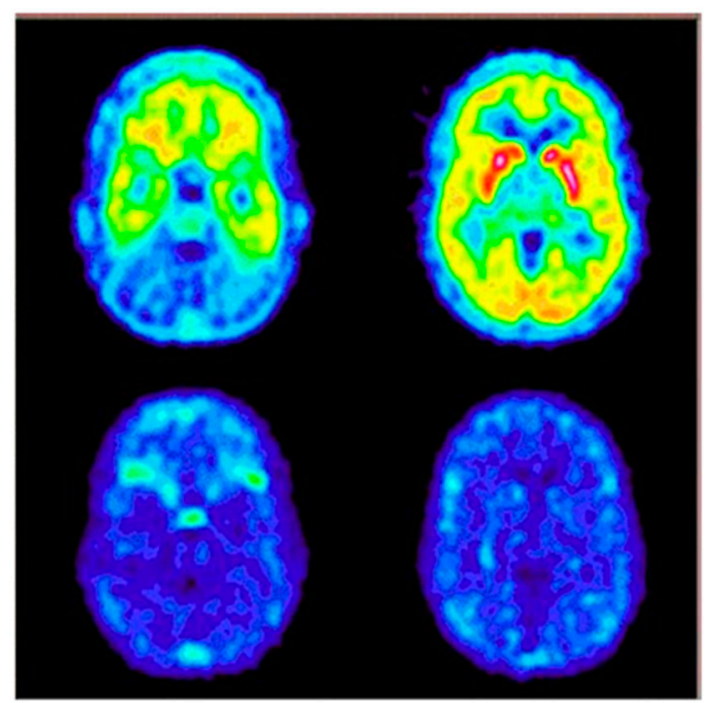

Figure 8. Predose (upper) and $100 \mathrm{mg}$ aprepitant postdose (bottom) PET scans in the transverse section at the level of cerebellum (left) and striatum (right) in a human subject. Warmer colours symbolise higher uptake of radiotracer $\left[{ }^{18} \mathrm{~F}\right] \mathrm{SPA}-\mathrm{RQ}$. Based on ratio method with cerebellum reference, estimated receptor occupancy by aprepitant for this subject was $94 \%$ at $1053 \mathrm{ng} / \mathrm{mL}$ of aprepitant in plasma [163].

NK1R occupancy PET mapping by the $\left[{ }^{18} \mathrm{~F}\right]$ SPA-RQ radiotracer was also applied in later clinical trials as verification of adequate target drug dose engagement. NK1R antagonists, aprepitant and its analogue L-759,274, were investigated in trials treating participants with major depressive disorder and anxiety disorder, respectively [76,78]. Unfortunately, both double-blind, randomised, placebo- and active-controlled, multicentre phase III clinical trials indicated not effective activity of aprepitant and L-759,274 for the treatment of depression or anxiety disorders, respectively. However, these researches demonstrated that radiotracer imaging can be used as a supportive tool in the proper context to validate negatively terminated trials.

$\left[{ }^{11}\right.$ C]GR205171 tracer application in clinical trials was explored intensively by GlaxoSmithKlein. It is perfectly illustrated in determination of casopitant plasma concentration correlation with receptor occupancy [164]. Baseline and post-casopitant oral dose PET-[ ${ }^{11}$ C]GR205171 brain imaging was performed in addition to collection of subject plasma for pharmacokinetic characterizations. The main goal of this study was to develop an estimation of suitable casopitant dose for subsequent patient clinical trials. Only the 15-30 mg drug dose was shown to achieve NK1R occupancy above 95\%, which is a higher concentration than previously reported casopitant doses applied in depression trials [165,166]. This quantitative result was based on radiotracer pharmacokinetic model of NK1R binding initially established in the study [165]. Similar PET studies using [ ${ }^{11}$ C]GR205171 were performed under phase 1 of interventional clinical trials to investigate receptor occupancy, safety, tolerability and pharmacokinetic features of rolapitant [167] and two other promising antagonists GSK1144814 [168] and GSK206136 [169]. Rolapitant PET evaluation indicated that a single oral treatment at $200 \mathrm{mg}$ was a sufficient dose to occupy more than $90 \%$ of cerebral NK1Rs. Moreover, this receptor occupancy level was maintained for $120 \mathrm{~h}$ post-drug administration. These results suggest that treatment can provide properly long antiemetic action in case of highly emetogenic chemotherapy. 
In 2005 at Amsterdam VU University Medical Centre a novel selective radiotracer $\left[{ }^{11} \mathrm{C}\right] \mathrm{R} 116301$ was developed (Figure 9) [170]. This radiotracer was evaluated in potential PET visualisation of NK1R in the human brain [171,172]. Similarly, as in above demonstrated cases, the highest uptake was recorded at striatum and lower in thalamus and other cortex regions. The cerebellar uptake level was negligible and nonspecific, as is presented in previous NK1R distribution reports. Receptor blocking with $125 \mathrm{mg}$ oral dose of aprepitant reduced significantly in the striatum and cortex imaging signals relative to the cerebellar level. Further investigation of $\left[{ }^{11} \mathrm{C}\right] \mathrm{R} 116301$ specific binding was performed in 11 healthy volunteers using a test-retest method where baseline imaging and imaging after treatment with known doses of aprepitant were obtained in the same subjects. Researchers recommended to examine the ROI of the cerebellum as a semiquantitative ratio method for clinical applications, mainly due to $\left[{ }^{11} \mathrm{C}\right] \mathrm{R} 116301$ fast specific binding kinetics enabling realization of PET scans in 60-90 min after injection. In comparison, $\left[{ }^{18} \mathrm{~F}\right] \mathrm{SPA}-\mathrm{RQ}$ has slower kinetics, reaching cerebral receptor binding equilibrium only $6 \mathrm{~h}$ after treatment. Such slow kinetics present a considerable limitation to routine application, even if the given radiotracer provides relatively high specific imaging signal. This stands in accordance with NK1R-ligand affinity order [149], where the highest affinity ligands are GR205171 and SPA-RQ, followed by aprepitant, R116301 and SP. However, the use of $\left[{ }^{11} \mathrm{C}\right] \mathrm{R} 116301$ in dynamic brain receptor imaging seems to be promising in various concentrations of endogenous SP, for instance, in pharmacological test investigations.<smiles>Cc1cccc(C)c1NC(=O)CN1CCN([C@H]2CCN(C(=O)c3cc(C(F)(F)F)cc(C(F)(F)F)c3)[C@H](Cc3ccccc3)C2)CC1</smiles>

$\left[{ }^{11} \mathrm{C}\right] \mathrm{R} 116301$<smiles>C[C@@H](O[C@H]1OCCN(Cc2n[nH]c(=O)[nH]2)[C@@H]1c1ccc(F)cc1)c1cc(C(F)(F)F)cc(C(F)(F)F)c1</smiles>

$\left[{ }^{14}\right.$ C]aprepitant

Figure 9. $\left[{ }^{11} \mathrm{C}\right] \mathrm{R} 116301$ (left) and exemplary $\left[{ }^{14} \mathrm{C}\right]$ aprepitant (right) structures.

In the course of drug development and final market approval, radiolabelled aprepitant, casopitant and netupitant need to be studied in terms of bioavailability [173-176]. Determination of absorption, distribution, metabolism and excretion features were performed on ${ }^{14} \mathrm{C}$-labelled derivatives of listed antagonists, synthesised for a biotransformation evaluation in rats, dogs and humans. The use of long-lived radionuclide traces for that purpose enabled investigation a range of metabolites (excreted or blood circuiting) after intravenous or oral administration. 
Table 6. List of selected radiolabelled NK1R antagonists.

\begin{tabular}{|c|c|c|c|}
\hline Radiotracer & Structure & Application & Reference \\
\hline $\begin{array}{l}{\left[{ }^{11} \mathrm{C}\right] \mathrm{CP}-96,345^{1}} \\
{\left[{ }^{11} \mathrm{C}\right] \mathrm{CP}-99,994^{1}} \\
{\left[{ }^{11} \mathrm{C}\right] \mathrm{CP}-643,051^{1}}\end{array}$ & $\begin{array}{l}\text { Investigational "lead } \\
\text { structure" compounds }\end{array}$ & Preclinical tests in animal models & $\begin{array}{l}{[146]} \\
{[147]} \\
{[148]}\end{array}$ \\
\hline $\begin{array}{c}{\left[{ }^{11} \mathrm{C}\right] \text { GR205171 }\left(\left[{ }^{11} \mathrm{C}\right] \text { vofopitant }\right)^{2}} \\
{\left[{ }^{18} \mathrm{~F}\right] \text { SPA-RQ }\left(\left[{ }^{18} \mathrm{~F}\right] \mathrm{L}-829,165\right){ }^{2}} \\
{\left[{ }^{18} \mathrm{~F}\right] \mathrm{FE}-\mathrm{SPA}-\mathrm{RQ}} \\
{\left[{ }^{11} \mathrm{C}\right] \mathrm{R} 116301^{3}}\end{array}$ & Optimized radiotracers & $\begin{array}{l}\text { Pharmacodynamics and } \\
\text { pharmacokinetics studies, } \\
\text { receptor occupancy imaging in } \\
\text { clinical trials }\end{array}$ & $\begin{array}{c}{[149,151,155-157,164-169]} \\
{[76,78,150,152,158-163]} \\
{[153,154]} \\
{[170-172]}\end{array}$ \\
\hline $\begin{array}{l}{\left[{ }^{14} \mathrm{C}\right] \text { aprepitant }} \\
\\
{\left[{ }^{14} \mathrm{C}\right] \text { casopitant }^{4}} \\
{\left[{ }^{14} \mathrm{C}\right] \text { netupitnat }}\end{array}$ & $\begin{array}{l}\text { Well known high-selective } \\
\text { antagonists indicated in } \\
\text { CINV }\end{array}$ & $\begin{array}{l}\text { ADME investigations in animals } \\
\text { and men }\end{array}$ & $\begin{array}{c}{[173]} \\
{[174,175]} \\
{[176]}\end{array}$ \\
\hline
\end{tabular}

${ }^{1}$ Structure illustrated in Figure $4 ;{ }^{2}$ Structure illustrated in Figure $5 ;{ }^{3}$ Structure illustrated in Figure 9; ${ }^{4}$ Structure of nonlabelled compound illustrated in Figure 3.

\section{Conculsions}

This review discusses precisely literature data concerning the chemical and biological aspects of natural and synthetic NK1R ligands in classical (targeted therapy) and nuclear (targeted radionuclide therapy) medicine. Despite that standard nonspecific cancer treatments (e.g. chemotherapy, radiation therapy) are still the dominant form of therapy, the specific cancer treatments - targeted radionuclide tumour therapy is increasingly used in clinical trials. Due to expression of NK1Rs in a wide variety of cancers, the NK1R/SP system can be used as a modulator of biological functions related to tumour cell proliferation (favouring tumour growth), angiogenesis and migration. However, because of relatively low stability of SP, its fragments and analogues, new NK1R ligands are constantly being investigated. It initiated innovative studies with the application of SP antagonists.

To summarize, use of PET radiotracers supports progress in NK1R antagonist development and facilitates clinical investigations in terms of NK1R system correlation with CNS pathologies. Moreover, molecular imaging has the potential to improve therapeutic monitoring and to explore the duration of pharmacological effects in course of targeted radionuclide therapy. Although several clinical trials using radiotracers based on NK1R antagonists have been conducted to date, no serious attempts have been made in the oncological space yet.

Author Contributions: Conceptualisation, A.M.-P and E.G.; writing, A.M.-P.; P.K.H. and E.G.; visualisation, P.K.H.; supervision, A.M.-P. and E.G.

Funding: This research was carried out within grants HOMING PLUS/2013-8/9, supported by the Foundation for Polish Science, and 2017/25/B/NZ7/01896, supported by the National Science Centre (Poland).

Conflicts of Interest: The authors declare no conflicts of interest.

\section{Abbreviations}

5-HT 3 R: 5-hydroxytryptamine receptor 3, serotonin receptor 3; AC: adenylyl cyclase; ACE: angiotensin-converting enzyme; AVP: vasopressin peptide; Bapa: biotinyl sulfone-5-aminopentanoic acid; BBB: blood-brain barrier; $\mathrm{BH}$ : Bolton-Hunter agent, 3-(3-iodo-4-hydroxyphenyl)propionic acid $N$-hydroxysuccinimide ester; Bmax: maximal concentration of binding sites; BP: binding potential; Bq: bequerel, Bzl: benzyl group; cAMP: cyclic adenosine monophosphate; Ci: curie; CINV: chemotherapy-induced nausea and vomiting; $\mathrm{CN}$ : isocyanide group; CNS: central nervous system; CSF: cerebrospinal fluid; CT: computed tomography; DOTA: 1,4,7,10-tetraazacyclododecane 1,4,7,10-tetracetic acid chelator; DTPA: pentetic acid, diethylenetriaminepentaacetic acid; DOTAGA: 1,4,7,10-tetraazacyclododecane-1-glutaric acid-4,7,10-triacetic acid chelator; EC: electron capture; EDDA: ethylenediamine- $N, N$-diacetic acid; EMA: European Medicines Agency; Emax: maximal emission energy; Emean: mean emission energy; GBM: glioblastoma multiforme; GPCR: G protein-coupled receptor; GSC: glioblastoma multiforme stem cell; Hcy: homocysteine; $\mathrm{HcyO}_{2}$ : homocysteine sulfone; HS: human serum; Hynic: hydrazinonicotinamide chelator; IC: interstitial cystitis; $\mathrm{IC}_{50}$ : half maximal inhibitory concentration; ID: injected dose; \%ID/g; percent of injected dose per gram of tissue mass; IGF-1: insulin-like growth factor 1; IMB: bifunctional chelator 1-imino-4-mercaptobutyl; $\mathrm{K}_{\mathrm{d}}$ : dissociation constant; keV: kiloelectronvolt; $\log \mathrm{P}$ : $\log$ arithm of partition coefficient; MeV: megaelectronvolt; MRI: magnetic resonance imaging tomography; NEP: neutral endopeptidase; NK1R: neurokinin 1 receptor; NK-1m: minority binding site of neurokinin 1 receptor; NK-1M: majority binding site of neurokinin 1 receptor; NK1R-Tr: truncated form of neurokinin 1 receptor; NK2R: neurokinin 2 receptor; NK3R: neurokinin 3 receptor; NKA: neurokinin A; NKB: neurokinin $B$; $\mathrm{NS}_{3}$ : 2,2' $2^{\prime \prime}$-nitrilotriethanethiol; OS: 
overall survival; PCN: tris(2-cyanoethyl)phosphine; PET: positron emission tomography; PFS: progression free survival; PLC: phospholipase C; PNS: peripheral nervous system; PONV: postoperative nausea and vomiting; ROI: region of interest; SAR: structure activity relationship; SP: Substance P; SPECT: single photon emission computed tomography; SPR: Substance P receptor; $S P R+$ : Substance P receptor-positive; $\mathrm{t}_{1 / 2}$ : half-life; TACR1: tachykinin receptor 1; TACR2: tachykinin receptor 2; TACR3: tachykinin receptor 3; US FDA: United States Food and Drug Administration.

\section{References}

1. Muñoz,M.; Coveñas, R. Neurokinin-1 receptor: A new promising target in the treatment of cancer. Discov. Med. 2010, 10, 305-313. [PubMed]

2. Muñoz, M.; Rosso, M.; Coveñas, R. The NK-1 receptor: A new target in cancer therapy. Curr. Drug Targets 2011, 12, 909-921. [CrossRef] [PubMed]

3. Garcia-Recio, S.; Gascón, P. Biological and Pharmacological Aspects of the NK1-Receptor. BioMed Res. Int. 2015. [CrossRef] [PubMed]

4. Yin, J.; Chapman, K.; Clark, L.D.; Shao, Z.; Borek, D.; Xu, Q.; Wang, J.; Rosenbaum, D.M. Crystal structure of the human $\mathrm{NK}_{1}$ tachykinin receptor. Proc. Natl. Acad. Sci. USA 2018, 115, 13264-13269. [CrossRef] [PubMed]

5. Harrison, S.; Geppetti, P. Substance P. Int. J. Biochem. Cell B 2001, 33, 555-576. [CrossRef]

6. Palma, C. Tachykinins and their receptors in human malignancies. Curr. Drug Targets 2006, 7, $1043-1052$. [CrossRef]

7. Chandrashekar, I.R.; Cowsik, S.M. Three-Dimensional Structure of the Mammalian Tachykinin Peptide Neurokinin A Bound to Lipid Micelles. Biophys. J. 2003, 85, 4002-4011. [CrossRef]

8. Steinhoff, M.S.; Mentzer, B.; Geppetti, P.; Pothoulakis, C.H.; Bunnett, N.W. Tachykinins and Their Receptors: Contributions to Physiological Control and the Mechanisms of Disease. Physiol. Rev. 2014, 94, $265-301$. [CrossRef] [PubMed]

9. Valentin-Hansen, L.; Park, M.; Huber, T.; Grunbeck, A.; Naganathan, S.; Schwartz, T.W.; Sakmar, T.P. Mapping Substance P Binding Sites on the Neurokinin-1 Receptor Using Genetic Incorporation of a Photoreactive Amino Acid. J. Biol Chem. 2014, 289, 18045-18054. [CrossRef]

10. Sachon, E.; Girault-Lagrange, S.; Chassaing, G.; Lavielle, S.; Sagan, S. Analogs of Substance P modified at the C-terminus which are both agonist and antagonist of the NK-1 receptor depending on the second messenger pathway. J. Pept. Res. 2002, 59, 232-240. [CrossRef]

11. Sagan, S.; Lavielle, S. Internalization of $[3 \mathrm{H}]$ substance $\mathrm{P}$ analogues in NK-1 receptor transfected CHO cells. Biochem. Biophys. Res. Commun. 2001, 282, 958-964. [CrossRef]

12. Sagan, S.; Quancard, J.; Lequin, O.; Karoyan, P.; Chassaing, G.; Lavielle, S. Conformational Analysis of the C-Terminal Gly-Leu-Met- $\mathrm{NH}_{2}$ Tripeptide of Substance P Bound to the NK-1 Receptor. Chem. Biol. 2005, 12, 555-565. [CrossRef]

13. Quancard, J.; Karoyan, P.; Sagan, S.; Convert, O.; Lavielle, S.; Chassaing, G.; Lequin, O. Characterization of the bioactive conformation of the C-terminal tripeptide Gly-Leu-Met- $\mathrm{NH}_{2}$ of substance $\mathrm{P}$ using [3-prolinoleucine10]SP analogues. Eur. J. Biochem. 2003, 270, 2869-2878. [CrossRef]

14. Alves, I.D.; Delaroche, D.; Mouillac, B.; Salamon, Z.; Tollin, G.; Hruby, V.J.; Lavielle, S.; Sagan, S. The Two NK-1 Binding Sites Correspond to Distinct, Independent, and Non-Interconvertible Receptor Conformational States as Confirmed by Plasmon-Waveguide Resonance Spectroscopy. Biochemistry 2006, 45, 5309-5318. [CrossRef]

15. Cordier, D.; Gerber, A.; Kluba, C.H.; Bauman, A.; Hutter, G.; Mindt, T.L.; Mariani, L. Expression of Different Neurokinin-1 Receptor (NK1R) Isoforms in Glioblastoma Multiforme: Potential Implications for Targeted Therapy. Cancer Biother. Radiopharm. 2014, 29, 221-226. [CrossRef]

16. Berger, M.; Neth, O.; Ilmer, M.; Garnier, A.; Salinas-Martín, M.V.; de Agustín Asencio, J.C.; von Schweinitz, D.; Kappler, R. Hepatoblastoma cells express truncated neurokinin-1 receptor and can be inhibited by aprepitant in vitro and in vivo. J. Hepatol. 2014, 60, 985-994. [CrossRef]

17. Rosso, M.; Robles-Frías, M.J.; Coveñas, R.; Salinas-Martín, M.V.; Muñoz, M. The NK-1 Receptor Is Expressed in Human Primary Gastric and Colon Adenocarcinomas and Is Involved in the Antitumor Action of L-733,060 and the Mitogenic Action of Substance P on Human Gastrointestinal Cancer Cell Lines. Tumour. Biol. 2008, 29, 245-254. [CrossRef] 
18. Feng, F.; Yang, J.; Tong, L.; Yuan, S.; Tian, Y.; Hong, L.; Wang, W.; Zhang, H. Substance P immunoreactive nerve fibres are related to gastric cancer differentiation status and could promote proliferation and migration of gastric cancer cells. Cell Biol. Int. 2011, 35, 623-629. [CrossRef]

19. Severini, C.; Improta, G.; Falconieri-Erspamer, G.; Salvadori, S.; Erspamer, V. The Tachykinin Peptide Family. Pharmacol. Rev. 2002, 54, 285-322. [CrossRef]

20. Łazarczyk, M.; Matyja, E.; Lipkowski, A. Substance P and its receptors-A potential target for novel medicines in malignant brain tumour therapies (mini review). Folia Neuropathol. 2007, 45, 99-107.

21. Graham, G.J.; Stevens, J.M.; Page, N.M.; Grant, A.D.; Brain, S.D.; Lowry, P.J.; Gibbins, J.M. Tachykinins regulate the function of platelets. Blood 2004, 104, 1058-1065. [CrossRef]

22. Datar, P.; Srivastava, S.; Coutinho, E.; Govil, G. Substance P: Structure, Function, and Therapeutics. Curr. Top. Med. Chem. 2004, 4, 75-103. [CrossRef]

23. Page, N.M. New challenges in the study of the mammalian Tachykinins. Peptides 2005, 26, 1356-1368. [CrossRef]

24. Ho, W.Z.; Douglas, S.D. Substance P and neurokinin-1 receptor modulation of HIV. J. Neuroimmunol. 2004, 157, 48-55. [CrossRef]

25. Mashaghi, A.; Marmalidou, A.; Tehrani, M.; Grace, P.M.; Pothoulakis, C.H.; Dana, R. Neuropeptide Substance $\mathrm{P}$ and the Immune Response. Cell Mol. Life Sci. 2016, 73, 4249-4264. [CrossRef]

26. Grady, E.F.; Garland, A.M.; Gamp, P.D.; Lovett, M.; Payan, D.G.; Bunnett, N.W. Delineation of the Endocytic Pathway of Substance P and Its Seven-Transmembrane Domain NK1 Receptor. Mol. Biol. Cell 1995, 6, 509-524. [CrossRef]

27. Muñoz, M.; Martinez-Armesto, J.; Coveñas, R. NK-1 receptor antagonists as antitumor drugs: A survey of the literature from 2000 to 2011. Expert Opin. Ther. 2012, 22, 735-746. [CrossRef]

28. Joos, G.F.; Germonpre, P.R.; Pauwels, R.A. Role of tachykinins in asthma. Allergy 2000, 55, 321-337. [CrossRef]

29. Yip, J.; Chahl, L.A. Localization of NK1 and NK3 receptors in guinea-pig brain. Regul. Pept. 2001, 98, 55-62. [CrossRef]

30. Skidgel, R.A.; Engelbrecht, S.; Johnson, A.R.; Erdös, E.G. Hydrolysis of substance P and neurotensin by converting enzyme and neutral endopeptidase. Peptides 1984, 5, 769-776. [CrossRef]

31. Skidgel, R.A.; Erdos, E.G. Angiotensin converting enzyme (ACE) and neprilysin hydrolyze neuropeptides: A brief history, the beginning and follow-ups to early studies. Peptides 2004, 25, 521-525. [CrossRef]

32. Lockridge, O. Substance P hydrolysis by human serum cholinesterase. J. Neurochem. 1982, 39, $106-110$. [CrossRef]

33. Sakurada, C.H.; Watanabe, C.H.; Sakurada, S.; Tan-No, K.; Sakurada, T. Major metabolites of substance $\mathrm{P}$ degraded by spinal synaptic membranes antagonize the behavioral response to substance $\mathrm{P}$ in rats. J. Pharm. Sci. 1999, 88, 1127-1132. [CrossRef]

34. Sandberg, B.E.; Lee, C.M.; Hanley, M.R.; Iversen, L.L. Synthesis and biological properties of enzyme-resistant analogues of substance P. Eur. J. Biochem. 1981, 114, 329-337. [CrossRef]

35. Wagner, E.; Partsch, G.; Dunky, A. Substance P and its cleavage products: Effects on interleukin-1 secretion of rheumatoid arthritis monocytes/macrophages. Arthritis Res. 2001, 3, P019. [CrossRef]

36. Skidgel, R.A.; Jackman, H.L.; Erdos, E.G. Metabolism of substance P and bradykinin by human neutrophils. Biochem. Pharmacol. 1991, 41, 1335-1344. [CrossRef]

37. Chubb, I.W.; Hodgson, A.J.; White, G.H. Acetylocholinoesterase hydrolyzes substance P. Neuroscience 1980, 5, 2065-2072. [CrossRef]

38. Mantyh, P.W. Neurobiology of substance P and the NK1 receptor. J. Clin. Psychiatry 2002, 63, 6-10.

39. Gesztesi, Z.; Scuderi, P.E.; White, P.F.; Wright, W.; Wender, R.H.; D'Angelo, R.; Black, L.S.; Dalby, P.L.; MacLean, D. Substance P (Neurokinin-1) antagonist prevents postoperative vomiting after abdominal hysterectomy procedures. Anesthesiology 2000, 93, 931-937. [CrossRef]

40. Aapro, M.S.; Walko, C.M. Aprepitant: Drug-drug interactions in perspective. Ann. Oncol. 2010, 21, 2316-2323. [CrossRef]

41. Schmidt, P.T.; Lordal, M.; Gazelius, B.; Hellstrom, P.M. Tachykinins potently stimulate human small bowel blood flow: A laser Doppler flowmetry study in humans. Gut 2003, 52, 53-56. [CrossRef]

42. Bernstein, C.N.; Robert, M.E.; Eysselein, V.E. Rectal substance P concentrations are increased in ulcerative colitis but not in Crohn's disease. Am. J. Gastroenterol. 1993, 88, 908-913. 
43. Goode, T.; O'Connell, J.; Anton, P.; Wong, H.; Reeve, J.; O’Sullivan, G.C.; Collins, J.K.; Shanahan, F. Neurokinin-1 receptor expression in inflammatory bowel disease: Molecular quantitation and localisation. Gut 2000, 47, 387-396. [CrossRef]

44. Evangelista, S. Involvement of tachykinins in intestinal inflammation. Curr. Pharm Des. 2001, 7, 19-30. [CrossRef]

45. McMahona, S.B.; Cafferty, W.B.J.; Marchand, F. Review, Immune and glial cell factors as pain mediators and modulators. Exp. Neurol. 2005, 192, 444-462. [CrossRef]

46. El-Raziky, M.S.; Gohar, N.; El-Raziky, M. Study of substance P, renine and aldosterone in chronic liver disease in Egyptian children. J. Top. Pediatr. 2005, 51, 320-323. [CrossRef]

47. Goto, T.; Tanaka, T. Tachykinins and tachykinin receptors in bone. Microsc. Res. Tech. 2002, 58, 91-97. [CrossRef]

48. Lorente, L. New prognostic biomarkers of mortality in patients undergoing liver transplantation for hepatocellular carcinoma. J. Neurochem. 2018, 24, 4230-4242. [CrossRef]

49. Goto, T.; Nakao, K.; Gunjigake, K.K.; Kido, M.A.; Kobayashi, S.; Tanaka, T. Substance P stimulates late-stage rat osteoblastic bone formation through neurokinin-1 receptors. Neuropeptides 2007, 41, 25-31. [CrossRef]

50. Nowicki, M.; Ostalska-Nowicka, D.; Konwerska, A.; Miskowiak, B. The predicting role of substance P in the neoplastic transformation of the hypoplastic bone marrow. J. Clin. Pathol. 2006, 59, 935-941. [CrossRef]

51. Nakamura, M.; Chikama, T.; Nishida, T. Synergistic effect with Phe-Gly-Leu-Met- $\mathrm{NH}_{2}$ of the C-terminal of substance $\mathrm{P}$ and insulin-like growth factor- 1 on epithelial wound healing of rabbit cornea. Br. J. Pharmacol. 1999, 127, 489-497. [CrossRef]

52. Fan, T.P.; Hu, D.E.; Guard, S.; Gresham, G.A.; Watling, K.J. Stimulation of angiogenesis by substance P and interleukin-1 in the rat and its inhibition by NK1 or interleukin-1 receptor antagonists. Br. J. Pharmacol. 1993, 110, 43-49. [CrossRef]

53. Merlo, A.; Mäcke, H.; Reubi, J.C.; Good, S. Radiolabeled Conjugates Based on Substance P and the Uses. Thereof. Patent No. WO 2004/082722, 30 September 2004.

54. Hoover, D.B.; Chang, Y.; Hancock, J.C.; Zhang, L. Action of Tachykinins Within the Heart and Their Relevance to Cardiovascular Disease. Jpn. J. Pharmacol. 2000, 84, 367-373. [CrossRef]

55. Cordier, D.; Forrer, F.; Bruchertseifer, F.; Morgenstern, A.; Apostolidis, C.; Good, S.; Müller-Brand, J.; Mäcke, H.; Reubi, J.C.; Merlo, A. Targeted alpha-radionuclide therapy of functionally critically located gliomas with ${ }^{213} \mathrm{Bi}-\mathrm{DOTA}-\left[\mathrm{Thi}^{8}{ }^{8} \mathrm{Met}\left(\mathrm{O}_{2}\right)^{11}\right]$-substance P: A pilot trial. Eur. J. Nucl. Med. Mol. Imaging 2010, 37, 1335-1344. [CrossRef]

56. Juszczak, M.; Stempniak, B. Melatonin inhibits the substance P-induced secretion of vasopressin and oxytocin from the rat hypothalamo-neurohypophysial system: In vitro studies. Brain Res. Bull. 2003, 59, 393-397. [CrossRef]

57. Juszczak, M.; Boczek-Leszczyk, E.; Stempniak, B. Effect of melatonin on the vasopressin secretion as influenced by tachykinin NK-1 receptor agonist and antagonist: In vivo and in vitro studies. J. Physiol. Pharmacol. 2007, $58,829-843$.

58. Feng, Z.; Xu, B. Inspiration from the mirror: D-amino acid containing peptides in biomedical approaches. Biomol. Concepts 2016, 7, 179-187. [CrossRef]

59. Kasheverov, I.E.; Utkin, Y.N.; Franke, P.; Tsetlin, V.I. Substance P derivatives with photoactivatable labels in the N-terminal part of the molecule. J. Pept. Res. 1997, 50, 408-414. [CrossRef]

60. Pradier, L.; Menager, J.; Le Guern, J.; Bock, M.D.; Heuillet, F.; Fardin, V.; Garret, C.; Doble, A.; Mayaux, J.F. Septide: An agonist for the NK1 receptor acting at a site distinct from substance P. Mol. Pharmmacol. 1994, 45, 287-293.

61. Sakurada, C.; Watanabe, C.; Inoue, M.; Tan-No, K.; Ando, R.; Kisara, K.; Sakurada, T. Spinal actions of GR73632, a novel tachykinin NK1 receptor agonist. Peptides 1999, 20, 301-304. [CrossRef]

62. Lazarus, L.H.; Diaugustine, R.P.; Soldato, C.M. A Substance with Immunoreactivity to the Peptide Physalaemin in Mammalian Respiratory Tissue. J. Exp. Lung Res. 1982, 3, 329-341. [CrossRef]

63. Champagne, D.; Ribeiro, E.J.M. Sialokinin I and II: Vasodilatory tachykinins from the yellow fever mosquito Aedes aegypti. Proc. Natl. Acad. Sci. USA 1994, 91, 138-142. [CrossRef]

64. Schwyzer, R. Membrane-assisted molecular mechanism of neurokinin receptor subtype selection. EMBO J. 1987, 6, 2255-2259. [CrossRef] 
65. Iwabuchi, Y.; Aoki, C.H.; Masuhara, T. Effects of Tachykinins on the Secretion of Fluid and Glycoproteins from the Submandibular Glands of Rat, Mouse, Hamster and Guinea Pig. Jpn. J. Pharmacol. 1989, 51, 428-431. [CrossRef]

66. Majumdar, A.K.; Howard, L.; Goldberg, M.R.; Hickey, L.; Constanzer, M.; Rothenberg, P.L.; Crumley, T.M.; Panebianco, D.; Bradstreet, T.E.; Bergman, A.J.; et al. Pharmacokinetics of Aprepitant After Single and Multiple Oral Doses in Healthy Volunteers. J. Clin. Pharmacol. 2006, 46, 291-300. [CrossRef]

67. Jin, Y.; Wu, X.; Guan, Y.; Gu, D.; Shen, Y.; Xu, Z.; Wei, X.; Chen, J. Efficacy and safety of aprepitant in the prevention of chemotherapy-induced nausea and vomiting: A pooled analysis. Support. Care Cancer 2012, 20, 1815-1822. [CrossRef]

68. Aapro, M.S.; Schmoll, H.J.; Jahn, F.; Carides, A.D.; Webb, R.T. Review of the efficacy of aprepitant for the prevention of chemotherapy-induced nausea and vomiting in a range of tumor types. Cancer Treat. Rev. 2013, 39, 113-117. [CrossRef]

69. Aoki, S.; Iihara, H.; Nishigaki, M.; Imanishi, Y.; Yamauchi, K.; Ishihara, M.; Kitaichi, K.; Itoh, Y. Difference in the emetic control among highly emetogenic chemotherapy regimens: Implementation for appropriate use of aprepitant. Mol. Clin. Oncol. 2013, 1, 41-46. [CrossRef]

70. Muñoz, M.; Coveñas, R. Safety of neurokinin-1 receptor antagonists. Expert Opin. Drug Saf. 2013, 12, $673-685$. [CrossRef]

71. Varuby Product Characteristics-EMEA/H/C/004196-T/0015. Available online: Ema.europa.eu/en/documents/ product-information/varuby-epar-product-information_en.pdf (accessed on 15 May 2019).

72. Cerenia Product Characteristics-EMEA/V/C/000106-IB/0035/G. Available online: Ema.europa.eu/en/ documents/product-information/cerenia-epar-product-information_en.pdf (accessed on 15 May 2019).

73. Akynzeo Product Characteristics-EMEA/H/C/003728-N/0022. Available online: Ema.europa.eu/en/ documents/product-information/akynzeo-epar-product-information_en.pdf (accessed on 15 May 2019).

74. Zunrisa Withdrawal Report EMEA/H/C/1040. Available online: Ema.europa.eu/en/documents/withdrawalreport/withdrawal-assessment-report-zunrisa_en.pdf (accessed on 15 May 2019).

75. Quartara, L.; Altamura, M.; Evangelista, S.; Maggi, C.A. Tachykinin receptor antagonists in clinical trials. Expert Opin. Investig. Drugs 2009, 18, 1843-1864. [CrossRef]

76. Keller, M.; Montgomery, S.; Ball, W.; Morrison, M.; Snavely, D.; Liu, G.; Hargreaves, R.; Hietala, J.; Lines, C.; Beebe, K.; et al. Lack of Efficacy of the Substance P (Neurokinin1 Receptor) Antagonist Aprepitant in the Treatment of Major Depressive Disorder. Biol. Psychiatry 2006, 59, 216-223. [CrossRef]

77. Huang, S.C.; Korlipara, V.L. Neurokinin-1 receptor antagonists: A comprehensive patent survey. Expert Opin. Ther. Pat. 2010, 20, 1019-1045. [CrossRef]

78. Michelson, D.; Hargreaves, R.; Alexander, R.; Ceesay, P.; Hietala, J.; Lines, C.; Reines, S. Lack of efficacy of L-759274, a novel neurokinin 1 (substance $\mathrm{P}$ ) receptor antagonist, for the treatment of generalized anxiety disorder. Int. J. Neuropsychopharmacol. 2013, 16, 1-11. [CrossRef]

79. Muñoz, M.; Coveñas, R. Involvement of substance P and the NK-1 receptor in human pathology. Amino Acids 2014, 46, 1727-1750. [CrossRef]

80. George, D.T.; Gilman, J.; Hersh, J.; Thorsell, A.; Herion, D.; Geyer, C.; Peng, X.; Kielbasa, W.; Rawlings, R.; Brandt, J.E.; et al. Neurokinin 1 receptor antagonism as a possible therapy for alcoholism. Science 2008, 319, 1536-1539. [CrossRef]

81. Torres, T.; Fernandes, I.; Selores, M.; Alves, R.; Lima, M. Aprepitant: Evidence of its effectiveness in patients with refractory pruritus continues. J. Am. Acad. Dermatol. 2012, 68, e14-e15. [CrossRef]

82. Yosipovitch, G.; Ständer, S.; Kerby, M.B.; Larrick, J.W.; Perlman, A.J.; Schnipper, E.F.; Zhang, X.; Tang, J.Y.; Luger, T.; Steinhoff, M. Serlopitant for the treatment of chronic pruritus: Results of a randomized, multicenter, placebo-controlled phase 2 clinical trial. J. Am. Acad. Dermatol. 2018, 78, 882-891. [CrossRef]

83. Muñoz, M.; Rosso, M.; Pérez, A.; Coveñas, R.; Rosso, R.; Zamarriego, C.; Piruat, J.I. The NK1 receptor is involved in the antitumoural action of L-733,060 and the mitogenic action of substance P on neuroblastoma and glioma cell lines. Neuropeptides 2005, 39, 427-432. [CrossRef]

84. Muñoz, M.; Rosso, M.; Pérez, A.; Coveñas, R.; Rosso, R.; Zamarriego, C.; Soult, J.A.; Montero, I. Antitumoral action of the neurokinin-1-receptor antagonist L-733,060 and mitogenic action of substance P on human retinoblastoma cell lines. Investig. Ophthalmol. Vis. Sci. 2005, 46, 2567-2570. [CrossRef] 
85. Muñoz, M.; Rosso, M.; Coveñas, R. The NK-1 receptor is involved in the antitumoural action of L-733,060 and in the mitogenic action of substance P on human pancreatic cancer cell lines. Lett. Drug Des. Discov. 2006, 3, 323-329. [CrossRef]

86. Muñoz, M.; Rosso, M.; Aguilar, F.J.; González-Moles, M.A.; Redondo, M.; Esteban, F. NK-1 receptor antagonists induce apoptosis and counteract substance P-related mitogenesis in human laryngeal cancer cell line HEp-2. Investig. New Drugs 2008, 26, 111-118. [CrossRef]

87. Muñoz, M.; Rosso, M.; Coveñas, R. A new frontier in the treatment of cancer: NK-1 receptor antagonists. Curr. Med. Chem. 2010, 17, 504-516. [CrossRef]

88. Muñoz, M.; Rosso, M.; Robles-Frías, M.J.; Salinas-Martín, M.V.; Coveñas, R. The NK-1 receptor is expressed in human melanoma and is involved in the antitumor action of the NK-1 receptor antagonist aprepitant on melanoma cell lines. Lab. Investig. 2010, 90, 1259-1269. [CrossRef]

89. Muñoz, M.; Rosso, M. The NK-1 receptor antagonist aprepitant as a broad-spectrum antitumor drug. Investig. New Drugs 2010, 28, 187-193. [CrossRef]

90. Muñoz, M.; Bernabeu-Wittel, J.; Coveñas, R. NK-1 as a melanoma target. Expert Opin. Ther. Targets 2011, 15, 889-897. [CrossRef]

91. Muñoz, M.; González-Ortega, A.; Coveñas, R. The NK-1 receptor is expressed in human leukemia and is involved in the antitumor action of aprepitant and other NK-1 receptor antagonists on acute lymphoblastic leukemia cell lines. Investig. New Drugs 2012, 30, 529-540. [CrossRef]

92. Muñoz, M.; González-Ortega, A.; Rosso, M.; Robles-Frías, M.J.; Carranza, A.; Salinas-Martín, M.V.; Coveñas, R. The substance P/neurokinin-1 receptor system in lung cancer: Focus on the antitumor action of neurokinin-1 receptor antagonists. Peptides 2012, 38, 318-325. [CrossRef]

93. Muñoz, M.; Rosso, M.; Coveñas, R. The NK-1 receptor antagonist L-732,138 induces apoptosis in human gastrointestinal cancer cell lines. Pharm. Rep. 2017, 69, 696-701. [CrossRef]

94. Muñoz, M.; Coveñas, R.; Esteban, F.; Redondo, M. The substance P/NK-1 receptor system: NK-1 receptor antagonists as anti-cancer drugs. J. Biosci. 2015, 40, 441-463. [CrossRef]

95. Muñoz, M.; Berger, M.; Rosso, M.; Gonzalez-Ortega, A.; Carranza, A.; Coveñas, R. Antitumor activity of neurokinin-1 receptor antagonists in MG-63 human osteosarcoma xenografts. Int. J. Oncol. 2014, 44, 137-146. [CrossRef]

96. Muñoz, M.; Coveñas, R. Involvement of substance P and the NK-1 receptor in cancer progression. Peptides 2013, 48, 1-9. [CrossRef]

97. Coveñas, R.; Muñoz, M. Cancer progression and substance P. Histol. Histopathol. 2014, 29, 881-890. [CrossRef]

98. Muñoz, M.; González-Ortega, A.; Salinas-Martín, M.V.; Carranza, A.; Garcia-Recio, S.; Almendro, V.; Coveñas, $R$. The neurokinin-1 receptor antagonist aprepitant is a promising candidate for the treatment of breast cancer. Int. J. Oncol. 2014, 45, 1658-1672. [CrossRef]

99. Kast, R.E.; Boockvar, J.A.; Brüning, A.; Cappello, F.; Chang, W.W.; Cvek, B.; Dou, Q.P.; Duenas-Gonzalez, A.; Efferth, T.; Focosi, D.; et al. A conceptually new treatment approach for relapsed glioblastoma: Coordinated undermining of survival paths with nine repurposed drugs (CUSP9) by the International Initiative for Accelerated Improvement of Glioblastoma Care. Oncotarget 2013, 4, 502-530. [CrossRef]

100. Muñoz, M.; Rosso, M.; González, A.; Saenz, J.; Coveñas, R. The broad-spectrum antitumor action of cyclosporin $\mathrm{A}$ is due to its tachykinin receptor antagonist pharmacological profile. Peptides 2010, 31, 1643-1648. [CrossRef]

101. González-Ortega, A.; Sánchez-Valderrábanos, E.; Ramiro-Fuentes, S.; Salinas-Martín, M.V.; Carranza, A.; Coveñas, R.; Muñoz, M. Uveal melanoma expresses NK-1 receptors and cyclosporin A induces apoptosis in human melanoma cell lines overexpressing the NK-1 receptor. Peptides 2014, 55, 1-12. [CrossRef]

102. Baum, R.P. Therapeutic Nuclear Medicine; Springer Publisher: Heidelberg, Germany, 2014.

103. International Atomic Energy Agency, Nuclear Data Services, Live Chart of Nuclides, Nuclear Structure and Decay Data. Available online: https://www-nds.iaea.org/relnsd/vcharthtml/VChartHTML.html (accessed on 28 July 2019).

104. Sjödin, L. Binding and internalization of ${ }^{125}$ I-Bolton-Hunter-substance-P by pancreatic acinar cells. Biochem. Biophys. Res. Commun. 1984, 124, 578-584. [CrossRef]

105. Larsen, P.J.; Mikkelsen, J.D.; Saermark, T. Binding of a iodinated substance P analog to a NK-1 receptor on isolated cell membranes from rat anterior pituitary. Endocrinology 1989, 124, 2548-2557. [CrossRef] 
106. Larsen, P.J.; Mikkelsen, J.D.; Mau, S.; Saermark, T. Binding and internalization of a iodinated substance P analog by cultured anterior pituitary cells. Mol. Cell Endocrinol. 1989, 65, 91-101. [CrossRef]

107. Larsen, P.J.; Saermark, T.; Mau, S.E. Binding of an iodinated substance P analogue to cultured anterior pituitary prolactin- and luteinizing hormone-containing cells. J. Histochem. Cytochem. 1992, 40, 487-493. [CrossRef]

108. Shigematsu, K.; Saavedra, J.M.; Kurihara, M. Specific substance P binding sites in rat thymus and spleen: In vitro autoradiographic study. Regul. Pept. 1986, 16, 147-156. [CrossRef]

109. Beaujouan, J.C.; Torrens, Y.; Saffroy, M.; Glowinski, J. Quantitative autoradiographic analysis of the distribution of binding sites for $\left[{ }^{125} \mathrm{I}\right]$ Bolton Hunter derivatives of eledoisin and substance $\mathrm{P}$ in the rat brain. Neuroscience 1986, 18, 857-875. [CrossRef]

110. Geraghty, D.P.; Maguire, C.M. Reduced [ $\left.{ }^{125} \mathrm{I}\right]$-Bolton Hunter substance P binding (NK1 receptors) in the basal forebrain nuclei of aged rats. Clin. Exp. Pharmacol. Physiol. 2002, 29, 1112-1115. [CrossRef]

111. Charlton, C.G.; Helke, C.J. Characterization and segmental distribution of 125I-Bolton-Hunter-labeled substance P binding sites in rat spinal cord. J. Neurosci. 1985, 5, 1293-1299. [CrossRef]

112. Cridland, R.A.; Yashpal, K.; Romita, V.V.; Gauthier, S.; Henry, J.L. Distribution of label after intrathecal administration of 125I-substance $P$ in the rat. Peptides 1987, 8, 213-221. [CrossRef]

113. Aanonsen, L.M.; Kajander, K.C.; Bennett, G.J.; Seybold, V.S. Autoradiographic analysis of ${ }^{125}$ I-substance $\mathrm{P}$ binding in rat spinal cord following chronic constriction injury of the sciatic nerve. Brain Res. 1992, 596, 259-268. [CrossRef]

114. Stucky, C.L.; Galeazza, M.T.; Seybold, V.S. Time-dependent changes in Bolton-Hunter-labelled ${ }^{125}$ I-substance $\mathrm{P}$ binding in rat spinal cord following unilateral adjuvant-induced peripheral inflammation. Neuroscience 1993, 57, 397-409. [CrossRef]

115. Maguire, C.M.; Geraghty, D.P. Comparison of [ $\left.{ }^{125} \mathrm{I}\right]$-bolton-hunter substance P binding in young and aged rat spinal cord. Brain Res. 1998, 786, 263-266. [CrossRef]

116. Liu, L.; Burcher, E. Radioligand binding and functional characterisation of tachykinin receptors in chicken small intestine. Naunyn Schmiedebergs Arch. Pharmacol. 2001, 364, 305-313. [CrossRef]

117. Garland, A.M.; Grady, E.F.; Payan, D.G.; Vigna, S.R.; Bunnett, N.W. Agonist-induced internalization of the substance P (NK1) receptor expressed in epithelial cells. Biochem. J. 1994, 303, 177-186. [CrossRef]

118. Beaujouan, J.C.; Torrens, Y.; Herbet, A.; Daguet, M.C.; Glowinski, J.; Prochiantz, A. Specific binding of an immunoreactive and biologically active 125I-labeled substance P derivative to mouse mesencephalic cells in primary culture. Mol. Pharmacol. 1982, 22, 48-55.

119. Liang, T.; Cascieri, M.A. Substance P receptor on parotid cell membranes. J. Neurosci. 1981, 1, $1133-1141$. [CrossRef]

120. Kieselbach, G.F.; Ragaut, R.; Knaus, H.G.; König, P.; Wiedermann, C.J. Autoradiographic analysis of binding sites for ${ }^{125}$ I-Bolton-Hunter-substance $P$ in the human eye. Peptides 1990, 11, 655-659. [CrossRef]

121. Buffington, C.A.; Wolfe, S.A. High affinity binding sites for $\left[{ }^{3} \mathrm{H}\right]$ substance $P$ in urinary bladders of cats with interstitial cystitis. J. Urol. 1998, 160, 605-611. [CrossRef]

122. Breeman, W.A.P.; Van Hagen, M.P.; Visser-Wisselaar, H.A.; van der Pluijm, M.E.; Koper, J.W.; Setyono-Han, B.; Bakker, W.H.; Kwekkeboom, D.J.; Hazenberg, M.P.; Lamberts, S.W.J.; et al. In Vitro and In Vivo Studies of Substance Receptor Expression in Rats with the New Analog [Indium-111-DTPA-Arg ${ }^{1}$ ]Substance P. J. Nucl. Med. 1996, 37, 108-117.

123. van Hagen, P.M.; Breeman, W.A.; Reubi, J.C.; Postema, P.T.; van den Anker-Lugtenburg, P.J.; Kwekkeboom, D.J.; Laissue, J.; Waser, B.; Lamberts, S.W.; Visser, T.J.; et al. Visualization of the thymus by substance P receptor scintigraphy in man. Eur. J. Nucl. Med. 1996, 23, 1508-1513. [CrossRef]

124. Ozker, S.K.; Hellman, R.S.; Krasnow, A.Z. Preparation of ${ }^{99 \mathrm{~m}} \mathrm{Tc}$ labeled substance P (SP). Appl. Radiat. Isot. 2002, 57, 729-732. [CrossRef]

125. Gniazdowska, E.; Koźmiński, P.; Fuks, L. Synthesis, radiochemistry and stability of the conjugates of technetium-99m complexes with Substance P. J. Radioanal. Nucl. Chem. 2013, 298, 1171-1177. [CrossRef]

126. Smilkov, K.; Janevik, E.; Guerrini, R.; Pasquali, M.; Boschi, A.; Uccelli, L.; Duatti, G.D.A. Preparation and first biological evaluation of novel Re-188/Tc-99m peptide conjugates with substance-P. Appl. Radiat. Isot. 2014, 92, 25-31. [CrossRef] 
127. Królicki, L.; Bruchertseifer, F.; Kunikowska, J.; Koziara, H.; Królicki, B.; Jakuciński, M.; Pawlak, D.; Apostolidis, C.; Mirzadeh, S.; Rola, R.; et al. Prolonged survival in secondary glioblastoma following local injection of targeted alpha therapy with 213Bi-substance P analogue. Eur. J. Nucl. Med. Mol. Imaging 2018, 45, 1636-1644. [CrossRef]

128. Mozaffari, S.; Erfani, M.; Beiki, D.; Johari Daha, F.; Kobarfard, F.; Balalaie, S.; Fallahi, B. Synthesis and preliminary evaluation of a new ${ }^{99 \mathrm{~m}} \mathrm{Tc}$ labeled Substance $\mathrm{P}$ analogue as a potential tumor imaging agent. Iranian J. Pharm. Res. 2015, 14, 97-110.

129. Lew, R.; Geraghty, D.P.; Drapeau, G.; Regoli, D.; Burcher, E. Binding characteristics of $\left[{ }^{125}\right.$ I]Bolton-Hunter $\left[\mathrm{Sar}^{9}, \mathrm{Met}\left(\mathrm{O}_{2}\right)^{11}\right]$ substance $\mathrm{P}$, a new selective radioligand for the NK1 receptor. Eur. J. Pharmacol. 1990, 184, 97-108. [CrossRef]

130. Tousignant, C.; Guillemette, G.; Drapeau, G.; Télémaque, S.; Dion, S.; Regoli, D. ${ }^{125} \mathrm{I}-\mathrm{BH}\left[\operatorname{Sar}^{9}, \operatorname{Met}\left(\mathrm{O}_{2}\right)^{11}\right]-\mathrm{SP}$, a new selective ligand for the NK-1 receptor in the central nervous system. Brain Res. 1990, 524, 263-270. [CrossRef]

131. Dam, T.V.; Martinelli, B.; Quirion, R. Autoradiographic distribution of brain neurokinin- $1 /$ substance $P$ receptors using a highly selective ligand $\left[{ }^{3} \mathrm{H}\right]-\left[\operatorname{Sar}^{9}, \operatorname{Met}\left(\mathrm{O}_{2}\right)^{11}\right]$-substance P. Brain Res. 1990, 531, 333-337. [CrossRef]

132. Oyen, W.J.G.; Bodei, L.; Giammarile, F.; Maecke, H.R.; Tenvall, J.; Luster, M.; Brans, B. Targeted therapy in nuclear medicine-current status and future prospects. Ann. Oncol. 2007, 18, 1782-1792. [CrossRef]

133. De Araújo, E.B.; Pujatti, P.B.; Barrio, O.; Caldeira, J.S.; Suzuki, M.F.; Mengatti, J. Radiolabeling of Substance P with Lutetium-177 and biodistribution study in AR42J pancreatic tumor xenografted Nude mice. J. Nucl. Med. 2008, 49, 6.

134. Kneifel, S.; Cordier, D.; Good, S.; Ionescu, M.C.S.; Ghaffari, A.; Hofer, S.; Kretzschmar, M.; Tolnay, M.; Apostolidis, C.; Waser, B.; et al. Local Targeting of Malignant Gliomas by the Diffusible Peptidic Vector 1,4,7,10-Tetraazacyclododecane-1-Glutaric Acid-4,7,10-Triacetic Acid-Substance P. Clin. Cancer Res. 2006, 12, 3843-3850. [CrossRef]

135. Cordier, D.; Forrer, F.; Kneifel, S.; Sailer, M.; Mariani, L.; Maecke, H.; Muller-Brand, J.; Merlo, A. Neoadjuvant targeting of glioblastoma multiforme with radiolabeled DOTAGA-substance P-Results from a phase I study. J. Neurooncol. 2010, 100, 129-136. [CrossRef]

136. Królicki, L.; Bruchertseifer, F.; Kunikowska, J.; Koziara, H.; Królicki, B.; Jakuciński, M.; Pawlak, D.; Apostolidis, C.; Mirzadeh, S.; Rola, R.; et al. Safety and efficacy of targeted alpha therapy with ${ }^{213}$ Bi-DOTA-substance P in recurrent glioblastoma. Eur. J. Nucl. Med. Mol. Imaging 2019, 46, 614-622. [CrossRef]

137. Ohgaki, H.; Dessen, P.; Jourde, B.; Horstmann, S.; Nishikawa, T.; Di Patre, P.L.; Burkhard, C.; Schüler, D.; Probst-Hensch, N.M.; Maiorka, P.C.; et al. Genetic pathways to glioblastoma: A population-based study. Cancer Res. 2004, 64, 6892-6899. [CrossRef]

138. Park, J.K.; Hodges, T.; Arko, L.; Shen, M.; Dello Iacono, D.; McNabb, A.; Olsen Bailey, N.; Kreisl, T.N.; Iwamoto, F.M.; Sul, J.; et al. Scale to predict survival after surgery for recurrent glioblastoma multiforme. J. Clin. Oncol. 2010, 28, 3838-3843. [CrossRef]

139. Majkowska-Pilip, A.; Rius, M.; Bruchertseifer, F.; Apostolidis, C.; Weis, M.; Bonelli, M.; Laurenza, M.; Królicki, L.; Morgenstern, A. In vitro evaluation of ${ }^{225}$ Ac-DOTA-substanceP for targeted alpha therapy of glioblastoma multiforme. Chem. Biol. Drug Des. 2018, 92, 1344-1356. [CrossRef]

140. Song, H.; Guerrero-Cazares, H.; Horti, A.; Wahl, R.L.; Quinones-Hinojosa, A.; Sgouros, G. Synthesis and Biodistribution of ${ }^{225}$ Ac-substance P for Intracavitary Radiopharmaceutical Therapy of High-grade Recurrent Glioma. In Cancer Research, Proceedings of the AACR 104th Annual Meeting, Washington, DC/Philadelphia, PA, USA, 6-10 April 2013; AACR: Washington, DC, USA; Philadelphia, PA, USA, 2013; Volume 73, p. 4533.

141. Jordan, C.T.; Guzman, M.L.; Noble, M. Cancer stem cells. N. Eng. J. Med. 2006, 355, 1253-1261. [CrossRef]

142. Bao, S.; Wu, Q.; McLendon, R.E.; Hao, Y.; Shi, Q.; Hjelmeland, A.B.; Dewhirst, M.W.; Bigner, D.D.; Rich, J.N. Glioma stem cells promote radioresistance by preferential activation of the DNA damage response. Nature 2006, 444, 756-760. [CrossRef]

143. Liu, G.; Yuan, X.; Zeng, Z.; Tunici, P.; Ng, H.; Abdulkadir, I.R.; Lu, L.; Irvin, D.; Black, K.L.; Yu, J.S. Analysis of gene expression and chemoresistance of $\mathrm{CD}_{133^{+}}$cancer stem cells in glioblastoma. Mol. Cancer 2006, 5 , 67-79. [CrossRef] 
144. Krolicki, L.; Bruchertseifer, F.; Morgenstern, A.; Kunikowska, J.; Koziara, H.; Krolicki, B.; Jakucinski, M.; Pawlak, D.; Apostolidis, C.; Rola, R.; et al. Safety and Therapeutic Efficacy of ${ }^{225}$ Ac-DOTA-SubstanceP for Therapy of Brain Tumors. J. Med. Imaging Radiat. Sci. 2019, 50, S22. [CrossRef]

145. Majkowska-Pilip, A.; Koźmiński, P.; Wawrzynowska, A.; Budlewski, T.; Kostkiewicz, B.; Gniazdowska, E. Application of Neurokinin-1 Receptor in Targeted Strategies for Glioma Treatment. Part I: Synthesis and Evaluation of Substance P Fragments Labeled with ${ }^{99} \mathrm{~m} \mathrm{Tc}$ and ${ }^{177} \mathrm{Lu}$ as Potential Receptor Radiopharmaceuticals. Molecules 2018, 23, 2542. [CrossRef]

146. Del Rosario, R.B.; Managner, T.J.; Gildersleeve, D.L.; Shreve, P.D.; Wieland, D.M.; Lowe III, J.A.; Drozda, S.E.; Snider, R.M. Synthesis of a Nonpeptide Carbon-11 Labeled Substance P Antagonist for PET Studies. Nucl. Med. Biol. 1993, 20, 545-547. [CrossRef]

147. Livni, E.; Babich, J.W.; Desa, M.C.; Godek, D.M.; Wilkinson, R.A.; Rubin, R.H.; Fischman, A.J. Synthesis of a 11 C-labeled NK1 Receptor Ligand for PET Studies. Nucl. Med. Biol. 1995, 22, 31-36. [CrossRef]

148. Bender, D.; Olsen, A.K.; Marthi, M.K.; Smith, D.F.; Cumming, P. PET evaluation of the uptake of N-[11C]methyl CP-643,051, an NK1 receptor antagonist, in the living porcine brain. Nucl. Med. Biol. 2004, 31, 699-704. [CrossRef]

149. Bergström, M.; Fasth, K.J.; Kilpatrick, G.; Ward, P.; Cable, K.M.; Wipperman, M.D.; Sutherland, D.R.; Langström, B. Brain uptake and receptor binding of two [11C]labelled selective high affinity NK1-antagonists, GR203040 and GR205171-PET studies in rhesus monkey. Neuropharmacology 2000, 39, 664-670. [CrossRef]

150. Nyman, M.J.; Eskola, O.; Kajander, J.; Vahlberg, T.; Sanabria, S.; Burns, D.; Hargreaves, R.; Solin, O.; Hietala, J. Gender and age affect NK1 receptors in the human brain-A positron emission tomography study with [18F]SPA-RQ. Int. J. Neuropsychopharmacol. 2007, 10, 219-229. [CrossRef]

151. Engman, J.; Åhs, F.; Furmark, T.; Linnman, C.; Pissiota, A.; Appel, L.; Frans, Ö.; Långström, B.; Fredrikson, M. Age, sex and NK1 receptors in the human brain-A positron emission tomography study with [11C]GR205171. Eur. Neuropsychopharmacol. 2012, 22, 562-568. [CrossRef]

152. Hietala, J.; Nyman, M.J.; Eskola, O.; Laakso, A.; Grönroos, T.; Oikonen, V.; Bergman, J.; Haaparanta, M.; Forsback, S.; Marjamäki, P.; et al. Visualization and Quantification of Neurokinin-1 (NK1) Receptors in the Human Brain. Mol. Imaging Biol. 2005, 7, 262-272. [CrossRef]

153. Haneda, E.; Higuchi, M.; Maeda, J.; Inaji, M.; Okauchi, T.; Ando, K.; Obayashi, S.; Nagai, Y.; Narazaki, M.; Ikehira, H.; et al. In Vivo Mapping of Substance P Receptors in Brains of Laboratory Animals by High-Resolution Imaging Systems. Synapse 2007, 61, 205-215. [CrossRef]

154. Okumura, M.; Arakawa, R.; Ito, H.; Seki, C.; Takahashi, H.; Takano, H.; Haneda, E.; Nakao, R.; Suzuki, H.; Suzuki, K.; et al. Quantitative Analysis of NK1 Receptor in the Human Brain Using PET with 18F-FE-SPA-RQ. J. Nucl. Med. 2008, 49, 1749-1755. [CrossRef]

155. Danfors, T.; Åhs, F.; Appel, L.; Linnman, C.; Fredrikson, M.; Furmark, T.; Kumlien, E. Increased neurokinin-1 receptor availability in temporal lobe epilepsy: A positron emission tomography study using [11C]GR205171. Epilepsy Res. 2011, 97, 183-189. [CrossRef]

156. Frick, A.; Åhs, F.; Linnman, C.; Jonasson, M.; Appel, L.; Lubberink, M.; Långström, B.; Fredrikson, M.; Furmark, T. Increased neurokinin-1 receptor availability in the amygdala in social anxiety disorder: A positron emission tomography study with [11C]GR205171. Transl. Psychiatry 2015, 5, e597. [CrossRef]

157. Michelgård, Å.; Appel, L.; Pissiota, A.; Frans, Ö.; Långström, B.; Bergström, M.; Fredrikson, M. Symptom Provocation in Specific Phobia Affects the Substance P Neurokinin-1 Receptor System. Biol. Psychiatry 2007, 61, 1002-1006. [CrossRef]

158. Fujimura, Y.; Yasuno, F.; Farris, A.; Liow, J.S.; Geraci, M.; Drevets, W.; Pine, D.S.; Ghose, S.; Lerner, A.; Hargreaves, R.; et al. Decreased Neurokinin-1 (Substance P) Receptor Binding in Patients with Panic Disorder: Positron Emission Tomographic Study with [18F]SPA-RQ. Biol. Psychiatry 2009, 66, 94-97. [CrossRef]

159. ClinicalTrials.gov Identifier: NCT00088738. Available online: https://clinicaltrials.gov/ct2/show/ NCT00088738 (accessed on 15 May 2019).

160. Jarcho, J.M.; Mandelkern, M.; Ebrat, B.; Smith, S.R.; Naliboff, B.D.; Labus, J.S.; Tillisch, K.; Mayer, E.A. Reduced Neurokinin-1 (Substance P) Receptor Binding in Patients With Irritable Bowel Syndrome: A Positron Emission Tomography Study With [18f]SPA-RQ. Gastroenterology 2010, 138, S372. [CrossRef]

161. ClinicalTrials.gov Identifier: NCT00102102. Available online: https://clinicaltrials.gov/ct2/show/NCT00102102 (accessed on 15 May 2019). 
162. ClinicalTrials.gov Identifier: NCT00547612. Available online: https://clinicaltrials.gov/ct2/show/ NCT00547612 (accessed on 15 May 2019).

163. Bergström, M.; Hargreaves, R.J.; Burns, H.D.; Goldberg, M.R.; Sciberras, D.; Reines, S.A.; Petty, K.J.; Ögren, M.; Antoni, G.; Långström, B.; et al. Human Positron Emission Tomography Studies of Brain Neurokinin 1 Receptor Occupancy by Aprepitant. Biol. Psychiatry 2004, 55, 1007-1012. [CrossRef]

164. Zamuner, S.; Rabiner, E.A.; Fernandes, S.A.; Bani, M.; Gunn, R.N.; Gomeni, R.; Ratti, E.; Cunningham, V.J. A pharmacokinetic PET study of NK1 receptor occupancy. Eur. J. Nucl. Med. Mol. Imaging 2012, 39, 226-235. [CrossRef]

165. Ranga, K.; Krishnan, R. Clinical experience with substance P receptor (NK1) antagonists in depression. J. Clin. Psychiatry 2002, 63, 25-29.

166. Ratti, E.; Bellew, K.; Bettica, P.; Bryson, H.; Zamuner, S.; Archer, G.; Squassante, L.; Bye, A.; Trist, D.; Krishnan, R.; et al. Results From 2 Randomized, Double-Blind, Placebo-Controlled Studies of the Novel NK1 Receptor Antagonist Casopitant in Patients with Major Depressive Disorder. J. Clin. Psychopharmacol. 2011, 31, 727-733. [CrossRef]

167. Poma, A.; Christensen, J.; Davis, J.; Kansra, V.; Martell, R.E.; Hedley, M.L. Phase 1 positron emission tomography (PET) study of the receptor occupancy of rolapitant, a novel NK-1 receptor antagonist. J. Clin. Oncol. 2017, 32. [CrossRef]

168. ClinicalTrials.gov Identifier: NCT01381419. Available online: https:/clinicaltrials.gov/ct2/show/NCT01381419 (accessed on 15 May 2019).

169. ClinicalTrials.gov Identifier: NCT01059578. Available online: https:/clinicaltrials.gov/ct2/show/NCT01059578 (accessed on 15 May 2019).

170. Van der Mey, M.; Janssen, C.G.M.; Janssens, F.E.; Jurzak, M.; Langlois, X.; Sommen, F.M.; Verreet, B.; Windhorst, A.D.; Leysen, J.E.; Herscheid, J.D.M. Synthesis and biodistribution of [11C]R116301, a promising PET ligand for central NK1 receptors. Bioorg. Med. Chem. 2005, 13, 1579-1586. [CrossRef]

171. Wolfensberger, S.P.A.; van Berckel, B.N.M.; Airaksinen, A.J.; Maruyama, K.; Lubberink, M.; Boellaard, R.; Carey, W.D.H.; Reddingius, W.; Veltman, D.J.; Windhorst, A.D.; et al. First Evaluation of [11C]R116301 as an In Vivo Tracer of NK1 Receptors in Man. Mol. Imaging Biol. 2009, 11, 241-245. [CrossRef]

172. Wolfensberger, S.P.; Maruyama, K.; van Berckel, B.N.; Lubberink, M.; Airaksinen, A.J.; Boellaard, R.; Luurtsema, G.; Reddingius, W.; Janssens, F.E.; Veltman, D.J.; et al. Quantification of the NK1 Receptor ligand [11C]R116301. Nucl. Med. Commun. 2011, 32, 896-902. [CrossRef]

173. Huskey, S.E.W.; Dean, B.J.; Doss, G.A.; Wang, Z.; Hop, C.E.C.A.; Anari, R.; Finke, P.E.; Robichaud, A.J.; Zhang, M.; Wang, B.; et al. The metabolic disposition of aprepitant, a Substance P receptor antagonist, in rats and dogs. Drug Metab. Dispos. 2004, 32, 246-258. [CrossRef]

174. Miraglia, L.; Pagliarusco, S.; Bordini, E.; Martinucci, S.; Pellegatti, M. Metabolic disposition of casopitant, a potent NK1 receptor antagonist, in mice, rats and dogs. Drug Metab. Dispos. 2010, 38, 1876-1891. [CrossRef]

175. Pellegatti, M.; Bordini, E.; Fizzotti, P.; Roberts, A.; Johnson, B.M. Disposition and Metabolism of Radiolabeled Casopitant in Humans. Drug Metab. Dispos. 2009, 37, 1635-1645. [CrossRef]

176. Spinelli, T.; Calcagnile, S.; Giuliano, C.; Rossi, G.; Lanzarotti, C.; Mair, S.; Stevens, L.; Nisbet, I. Netupitant PET Imaging and ADME Studies in Humans. J. Clin. Pharmacol. 2014, 54, 97-108. [CrossRef]

(C) 2019 by the authors. Licensee MDPI, Basel, Switzerland. This article is an open access article distributed under the terms and conditions of the Creative Commons Attribution (CC BY) license (http://creativecommons.org/licenses/by/4.0/). 